\title{
Bacteria associated with cockroaches: health risk or biotechnological opportunity?
}

\author{
Juan Guzman ${ }^{1}$ (D) Andreas Vilcinskas ${ }^{1,2}$ (D) \\ Received: 2 June 2020 / Revised: 14 October 2020 / Accepted: 21 October 2020 / Published online: 31 October 2020 \\ (C) The Author(s) 2020
}

\begin{abstract}
Cockroaches have existed for 300 million years and more than 4600 extant species have been described. Throughout their evolution, cockroaches have been associated with bacteria, and today Blattabacterium species flourish within specialized bacteriocytes, recycling nitrogen from host waste products. Cockroaches can disseminate potentially pathogenic bacteria via feces and other deposits, particularly members of the family Enterobacteriaceae, but also Staphylococcus and Mycobacterium species, and thus, they should be cleared from sites where hygiene is essential, such as hospitals and kitchens. On the other hand, cockroaches also carry bacteria that may produce metabolites or proteins with potential industrial applications. For example, an antibiotic-producing Streptomyces strain was isolated from the gut of the American cockroach Periplaneta americana. Other cockroach-associated bacteria, including but not limited to Bacillus, Enterococcus, and Pseudomonas species, can also produce bioactive metabolites that may be suitable for development as pharmaceuticals or plant protection products. Enzymes that degrade industrially relevant substrates, or that convert biomasses into useful chemical precursors, are also expressed in cockroach-derived bacteria and could be deployed for use in the food/feed, paper, oil, or cosmetics industries. The analysis of cockroach gut microbiomes has revealed a number of lesser-studied bacteria that may form the basis of novel taxonomic groups. Bacteria associated with cockroaches can therefore be dangerous or useful, and this review explores the bacterial clades that may provide opportunities for biotechnological exploitation.
\end{abstract}

\section{Key points}

- Members of the Enterobacteriaceae are the most frequently cultivated bacteria from cockroaches.

- Cultivation-independent studies have revealed a diverse community, led by the phyla Bacteroidetes and Firmicutes.

- Although cockroaches may carry pathogenic bacteria, most strains are innocuous and may be useful for biotechnological applications.

Keywords Blattodea $\cdot$ Cockroach $\cdot$ Microbiome $\cdot$ Bacteria $\cdot$ Pathogens $\cdot$ Application $\cdot$ Biotechnology

\section{Introduction to cockroach biology and evolution}

Supplementary Information The online version contains supplementary material available at https://doi.org/10.1007/s00253-02010973-6.

Juan Guzman

juan.guzman@ime.fraunhofer.de

1 Department of Bioresources, Fraunhofer Institute for Molecular Biology and Applied Ecology, Ohlebergsweg 12, 35392 Giessen, Germany

2 Institute for Insect Biotechnology, Justus-Liebig-University of Giessen, Heinrich-Buff-Ring 26-32, 35392 Giessen, Germany
Cockroaches are hemimetabolous insects of the order Blattodea, which also includes termites. Their distinguishing morphological characters include a flattened body, a shieldlike laminar structure (pronotum) covering the head and thorax, and the presence of tegmena (sclerotized forewings) and long antennae (Dettner and Peters 2010). Cockroaches are resilient insects, and most species can endure prolonged starvation and dehydration. For example, Periplaneta americana can survive for $\sim 1$ month without food or water (Willis and Lewis 1957). Cockroaches, like other insects, can become cannibalistic when nutrients are scarce, but cannibalism is 
not observed exclusively during starvation: some female cockroaches eat males after copulation in a similar manner to mantises (Richardson et al. 2010). Cockroaches can also reproduce by parthenogenesis, although fewer eggs are laid in comparison to sexual reproduction (Wharton and Wharton 1957). In addition, some female cockroaches can store sperm for life after a single copulation event, allowing eggs to be fertilized and laid without the presence of a male (Bell et al. 2007). Almost all cockroaches harbor endosymbiotic bacteria conferring the ability to recycle nitrogen from urea and ammonia wastes back to amino acids (Sabree et al. 2009). Overall, these biological mechanisms contribute to the fitness and success of cockroaches in the face of environmental challenges.

The order Blattodea is divided into three superfamilies: Blaberoidae, Blattoidea (which also contains the termites), and Corydiodea (Wang et al. 2017; Ware et al. 2008). The fossil register shows a large number of cockroach-like (roachoid) specimens dating from the Late Carboniferous period spanning between 323 and 299 Mya (Zhang et al. 2013b). Such carboniferous fossils, which were abundant by 315 Mya, feature a long, external oviposition system (Hornig et al. 2018). They are considered to be ancestors of other taxa, including the mantises (Mantodea), and are thus not true cockroaches (Legendre et al. 2015). The greatest diversification leading to modern cockroaches occurred during the Cretaceous, probably in Siberia (Roth 2003; Vršanský 2004). Today (August 2020), there are 4685 species of cockroaches registered in the cockroach online database (Beccaloni 2014). The superfamily Blaberoidea is the largest with 3596 species, followed by Blattoidea with 799, and Corydiodea with 290 (Online Resource 1). The families with the greatest number of species are Ectobiidae and Blaberidae (both from superfamily Blaberoidea), with 2354 and 1242 species, respectively (Fig. 1a). The genus with the largest number of species is Rhabdoblatta with 151 species, followed by Ischnoptera with 100, Phyllodromica with 96, and Balta with 91 . Surprisingly, there are only seven published articles that contain the word "Rhabdoblatta" in the title, and these are exclusively observational studies with species descriptions. We observed similar trends for most other cockroach genera. The exceptions were Pe. americana and Blattella germanica, which are common household cockroaches often considered as domiciliary pests. Most research on cockroach-associated microbes has focused on evidence that cockroaches carry pathogens (Rampal et al. 1983; Roth and Willis 1957; Strand and Brooks 1977). PubMed searches with "pathogens + cockroaches" in the title, abstract and keywords generated about half as many hits as "bacteria + cockroaches" and "gut + cockroaches," and hits for the query "microbiome + cockroaches" only appeared in the last two decades, evidently because the term microbiome is relatively recent (Fig. 1b). Insect research has focused predominantly on flies, with more than

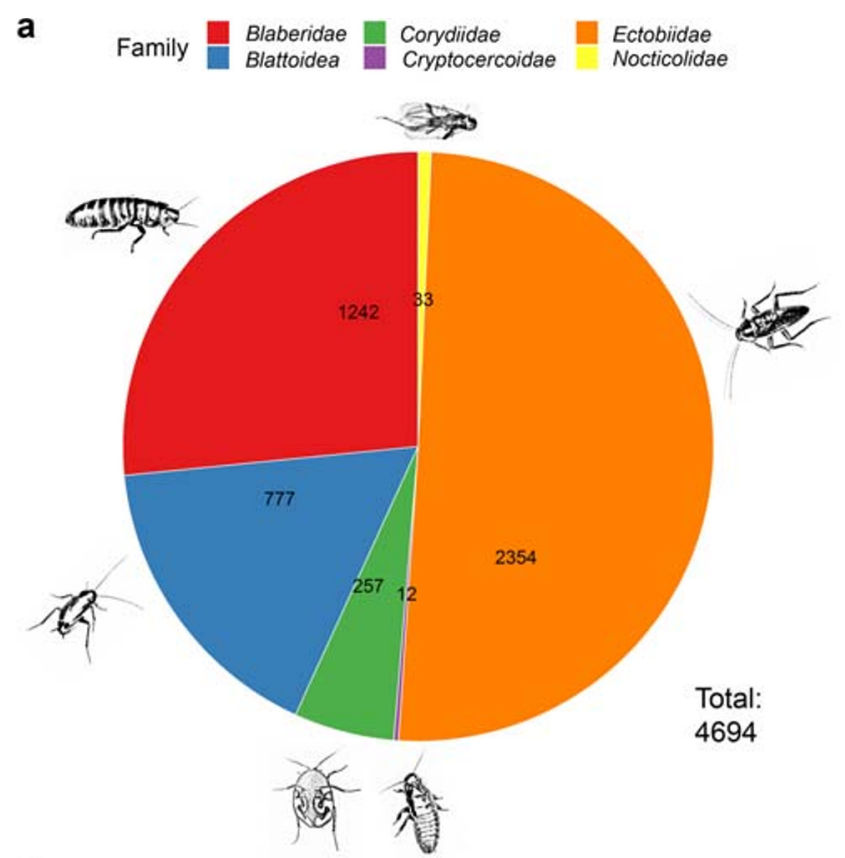

b

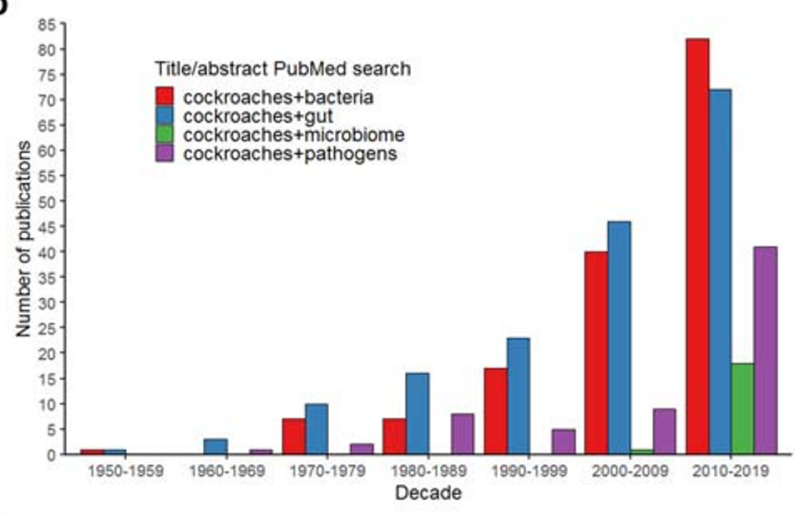

C

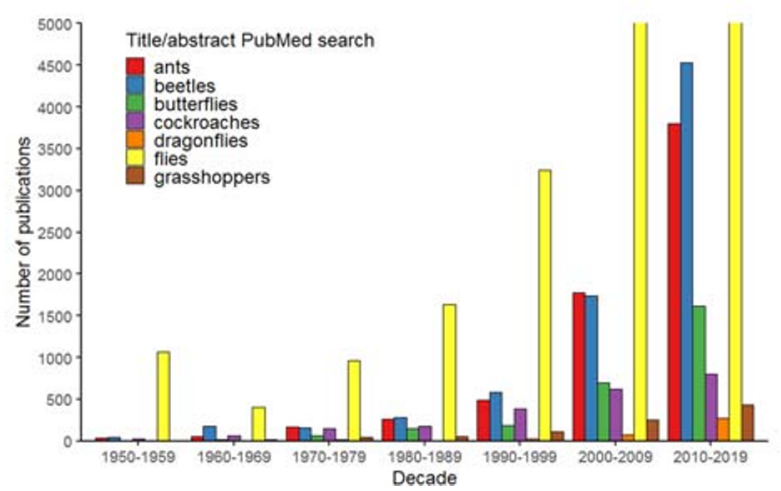

Fig. 1 Frequency of research articles focusing on cockroaches and specific families thereof. a Number of cockroach species in each family of the order Blattodea (excluding termites). b Number of publications found in PubMed using the term cockroaches + (bacteria, gut, microbiome or pathogens) in the title, abstract, and keywords by decade since 1950. c Number of publications found in PubMed using search terms representing different orders of insects in the title, abstract and keywords by decade since 1950 
12,000 publications in the last decade, followed by beetles, ants, and butterflies (Fig. 1c). Cockroaches have received comparatively little attention, with $\sim 1000$ publications in the last decade, but still more than dragonflies and grasshoppers. Interest in cockroach research has increased due to their use as food/feed and as a source of pharmaceutical ingredients in China (Feng et al. 2018; Gao et al. 2018). More than 99\% of cockroach species are not domiciliary pests, instead of living among decaying leaves, under tree bark, under stones, or in soil, and this large and untapped resource is likely to provide a bountiful source of microbial diversity. Several recent studies have suggested that the exploration of cockroach microbiomes will reveal as yet unclassified and uncultivated bacterial taxa (Lampert et al. 2019; Richards et al. 2017; Tegtmeier et al. 2018; Tinker and Ottesen, 2016). In this systematic review, we therefore discuss the collective body of literature on cockroach-associated bacteria identified either by conventional isolation and cultivation methods or by molecular biology. We assess whether these bacteria pose a danger as pathogens or constitute a reservoir of unexplored diversity with potential applications for biotechnology, medicine, agriculture, and industry.

\section{General outlook for cockroach-associated bacteria}

Wild insects are associated with microbes under varied levels of dependence, ranging from mutualistic primary symbionts typically living inside specialized cells (bacteriocytes or mycetocytes) to facultative secondary symbionts often circulating in the gut and essentially integrating into a variable community (Moya et al. 2008). Cockroaches are an interesting model for studying bacterial endosymbiosis, because obligate intracellular Blattabacterium species are found stably in the order Blattodea but not in termites, they are transferred vertically, they have yet to be cultured outside their hosts, and they are involved in nitrogen recycling (Brooks and Richards 1966; Perru 2007; Sabree et al. 2009). Given their variable nature, cockroach secondary symbionts are less stable, but both culture-dependent and culture-independent studies have shown that some taxonomic clades are encountered more frequently. Cockroach gut bacteria are systematically transmitted by coprophagy because feces are often meals and constitute the first nutrient provided by filial proctodeal trophallaxis to neonates (Nalepa et al. 2001). Cannibalism, necrophagy, and feeding with exuviae (Bell et al. 2007) are alternative routes for the transmission of microflora across a colony. The three major anatomical compartments of the cockroach gut have marked differences in $\mathrm{pH}$, redox potential, and hydrogen pressure (Cruden and Markovetz 1987; Lampert et al. 2019; Schauer et al. 2012; Vinokurov et al. 2007). The central portions of the cockroach midgut and the hindgut tend to be anoxic and therefore provide a good source of anaerobic bacteria.

Cockroaches are unable to synthesize certain amino acids and either acquire them in their diet or rely on symbionts. Blattabacteria are aerobic flavobacteria located within bacteriocytes in the cockroach fat tissue, but always in close proximity to specialized uric acid-containing urocytes (Brooks 1970). Detailed genomic analysis of Blattabacterium sp. BPLAN from Pe. americana revealed that $13 \%$ of its protein-encoding genes are required for amino acid biosynthesis and $7.8 \%$ are needed for the production of coenzymes (Sabree et al. 2009). Under deprivation, the insect host transforms uric acid (stored as urate in urocytes) into urea, which is then imported by blattabacteria and converted to ammonia (Patiño-Navarrete et al. 2014). The blattabacterial enzyme glutamate dehydrogenase (GdhA) catalyzes the addition of ammonia to 2-oxoglutarate yielding D-glutamic acid, which can be then transformed into most other amino acids, with the exception of L-asparagine and L-glutamine provided by the host (Patiño-Navarrete et al. 2014; Sabree et al. 2009). The blattabacterial pathways for the synthesis of glycine, Lmethionine, L-proline, and L-serine are incomplete, but glycine and L-proline are abundant in the hemolymph, and thus, the maintenance of these pathways is unnecessary (PatiñoNavarrete et al. 2014). Some Blattabacterium strains (particularly those from xylophagous cockroaches) have fully or partially lost their ability to synthesize certain amino acids, but they all retain full pathways for L-alanine, L-aspartic acid, L-glutamic acid, L-histidine, L-phenylalanine, and L-tyrosine biosynthesis (Tokuda et al. 2013; Vicente et al. 2018). The knowledge gained from studying amino acid biosynthesis in Blattabacterium may be used in the future for the design of synthetic organisms that sustain the production of amino acids, for example, in waste-management settings.

The brain lysate and hemolymph of Pe. americana showed antibacterial activity against Staphylococcus aureus and Escherichia coli (Ali et al. 2017; Latifi et al. 2015). Because the antimicrobial activity of the hemolymph was induced by abdominal sublethal injection with viable $E$. coli cells (Basseri et al. 2016), innate immunity is probably involved in the response (Kim et al. 2016). Although cockroach antimicrobial peptides such as periplanetasin-2 are probably involved in the antimicrobial effect of the hemolymph (Lee et al. 2019; Yun et al. 2017), the activity is retained in ethanol and ethyl acetate extracts that would denature proteins (Kui et al. 2013). This suggests the presence of small antimicrobial molecules which may be of microbial origin (Ali et al. 2017). In addition, the feces of the xylophagous cockroach Cryptocercus punctulatus showed antifungal activity linked to compounds produced by gut microbes (Rosengaus et al. 2013). Very recently, a species of Streptomyces producing actinomycin $\mathrm{X}_{2}$ and collismycin was isolated from the gut of Pe. americana (Chen et al. 2020). Bacteria in cockroaches are likely to produce antimicrobial 
compounds less toxic than those found in soil bacteria, because the host must survive exposure to these agents. Insects have been recognized as important sources of microorganisms that produce bioactive molecules (Beemelmanns et al. 2016; Shi and Bode 2018), and cockroaches in particular, given their distinct evolutionary history and resilient nature, are home to bacteria with interesting metabolic capabilities (Table 1).

\section{Are cockroaches truly responsible for human diseases?}

Many cockroaches have been sampled in hospitals and health centers, and given the nature of the bacteria cultivated from these species, the insects have been blamed for nosocomial infections (Fakoorziba et al. 2014; Fotedar et al. 1991; Gliniewicz et al. 2003; Pai et al. 2004; Tilahun et al. 2012). Two classical studies linked the eradication of cockroaches in health centers to a lower frequency of infections, particularly with Salmonella typhimurium (Graffar and Mertens 1950), and to lower rates of hepatitis (Tarshis 1962). There is strong evidence that Helicobacter pylori, mycobacteria, Pseudomonas aeruginosa, Salmonella spp., and other bacteria can survive passage through the cockroach digestive system (Allen 1987; Ash and Greenberg 1980; Clot and Vago 1970; Fotedar and Banerjee 1993; Imamura et al. 2003; Klowden and Greenberg 1977; Stek 1982). Because these insects typically feed on decaying organic material, there is little doubt that they can disseminate pathogenic bacteria. In addition, some of the bacterial isolates from cockroaches show antibiotic resistance (Abdolmaleki et al. 2019; Bouamamaa et al. 2010; Islam et al. 2016; Menasria et al. 2015; Pai et al. 2005; Prado et al. 2006; Tilahun et al. 2012). Taken together, these data support the general view that cockroaches are dangerous pests in human domiciles and healthcare settings, acting as vectors for bacterial infections. However, there is no direct proof that cockroaches spread nosocomial infections, and the link between eradication and lower infection rates could be related to a more general improvement in cleanliness. Undisputed evidence would ideally require experiments following Koch's postulates, such as the confirmation of identical serotypes in cockroaches and hospital patients. To the best of our knowledge, such studies have seldom been conducted. In one study, Klebsiella pneumoniae strains in insects and humans were indistinguishable, supporting the involvement of cockroaches in the dissemination of infections (Cotton et al. 2000). However, an analogous study on $P$. aeruginosa showed that the strains were different (Saitou et al. 2010). A recent review highlighting the association between cockroaches and infectious diseases (Donkor 2019) concluded that, although cockroaches increase risk and should not be tolerated in hospitals, there is not yet any definitive proof of

Table 1 Summary of bacterial strains isolated from cockroaches with potential biotechnological applications

\begin{tabular}{|c|c|c|c|c|}
\hline Phylum & Species/strain & Sources & Biotechnological application & References \\
\hline Actinobacteria & $\begin{array}{l}\text { Streptomyces globisporus } \\
\text { WA5-2-7 }\end{array}$ & $\begin{array}{l}\text { Periplaneta } \\
\text { americana }\end{array}$ & $\begin{array}{l}\text { Actinomycin X2 and collismycin A } \\
\text { antibiotics }\end{array}$ & Chen et al. (2020) \\
\hline \multirow[t]{6}{*}{ Firmicutes } & Bacillus cereus $\mathrm{B} 1$ & Blaberus craniifer & Insecticidal phospholipase $\mathrm{C}$ & $\begin{array}{l}\text { Ratcliffe and Rowley (1984); } \\
\text { Rahmet-Alla and Rowley (1989); } \\
\text { Rahmet-Alla and Rowley (1990) }\end{array}$ \\
\hline & Bacillus sp. $29 \mathrm{~K}$ & $\begin{array}{l}\text { Periplaneta } \\
\text { americana }\end{array}$ & $\begin{array}{l}\text { Keratinolytic and proteolytic } \\
\text { enzymes }\end{array}$ & Sharma et al. (2019) \\
\hline & Bacillus subtilis BGI-1 & Blatte. germanica & Fungicidal metabolites & Huang et al. (2013) \\
\hline & Enterococcus faecalis E18 & $\begin{array}{l}\text { Undefined } \\
\text { cockroach }\end{array}$ & Antibacterial bacteriocins & David et al. (2012) \\
\hline & Breznakia blatticola ErySL & $\begin{array}{c}\text { Shelfordella } \\
\text { lateralis }\end{array}$ & Formate, ethanol, acetate producer & Tegtmeier et al. (2016a) \\
\hline & Clostridium sp. & Eublaberus posticus & Carboxymethylcellulose decomposer & Cruden and Markovetz (1979) \\
\hline \multirow[t]{4}{*}{ Proteobacteria } & Shimwellia blattae DSM 4481 & Blatta orientalis & Cobalamin producer & $\begin{array}{l}\text { Andres et al. (2004); } \\
\text { Brzuszkiewicz et al. (2012); } \\
\text { Burgess et al. (1973) }\end{array}$ \\
\hline & Pseudomonas reactans BGI-14 & Blattella germanica & Fungicidal metabolites & Zhang et al. (2013a) \\
\hline & $\begin{array}{l}\text { Pseudomonas aeruginosa } \\
\text { BGf-2 }\end{array}$ & Blattella germanica & Antifungal protein producer & Zhang et al. (2020) \\
\hline & $\begin{array}{l}\text { Stenotrophomonas maltophilia } \\
\quad \text { OG2 }\end{array}$ & Blatta orientalis & Endosulfan degradation & Ozdal et al. (2017) \\
\hline Spirochaetes & $\begin{array}{l}\text { Alkalispirochaeta } \\
\text { cellulosivorans } \mathrm{JC} 227\end{array}$ & $\begin{array}{l}\text { Cryptocercus } \\
\text { punctulatus }\end{array}$ & Cellulose degradation at basic $\mathrm{pH}$ & Sravanthi et al. (2016) \\
\hline Verrucomicrobia & Ereboglobus luteus Ho45 & $\begin{array}{l}\text { Shelfordella } \\
\text { lateralis }\end{array}$ & Anaerobic degradation & $\begin{array}{l}\text { Tegtmeier et al. (2018); } \\
\text { Wang et al. (2018) }\end{array}$ \\
\hline
\end{tabular}


their direct involvement in the transmission of infections to patients.

\section{Cultivation-dependent vs cultivation-independent analysis}

There is a large body of literature describing bacteria cultivated from cockroaches (Online Resource 2). To organize the data in a meaningful way, we generated a bidimensional heat map plot (Fig. 2). More than 20 studies have focused on the cultivation of bacteria from Pe. americana and Blatte. germanica (Akinjogunla et al. 2012; Cruden and Markovetz 1987; Fakoorziba et al. 2014; Oothuman et al. 1989; Rampal et al. 1983; Roth and Willis 1960; Strand and Brooks 1977; Wannigama et al. 2014). Other cockroaches including Blatta orientalis (Burgess et al. 1973) and Eublaberus posticus and Supella longipalpa (Le Guyader et al. 1989) have also been the subject of multiple cultivation studies (Cruden and Markovetz 1987; Roth and Willis 1960; Strand and Brooks 1977). Most bacteria cultivated from cockroaches represent the phylum Proteobacteria (Fig. 2). This may reflect the routine use of selective culture media in medical bacteriology (including MacConkey, deoxycholate citrate, and eosin methylene blue agars), which favor the recovery of Gram-negative bacteria. Further selectivity is introduced by the routine incubation temperature of $37{ }^{\circ} \mathrm{C}$. Unsurprisingly, many studies have reported the cultivation of coliform bacteria (family Enterobacteriaceae, class Gammaproteobacteria) from cockroaches. A major advantage of the cultivation-dependent approach is that it facilitates the genomic, transcriptomic, proteomic, and metabolomic analyses of the isolated bacteria, allowing direct biotechnological exploitation. On the other hand, culture-independent methods offer a more authentic vision of the true diversity of a microbial niche and are considered the gold standard for the analysis of bacterial communities. However, the data should be interpreted with caution because it can be difficult to generalize due to the changing composition of communities over time and differences between individuals in the same community (Hornung et al. 2019; Schloss 2018). The results of microbiome studies are influenced by biological factors such as age, sex, and health; environmental factors such as diet, temperature, and humidity; and differences in analytical methods (DNA extraction,
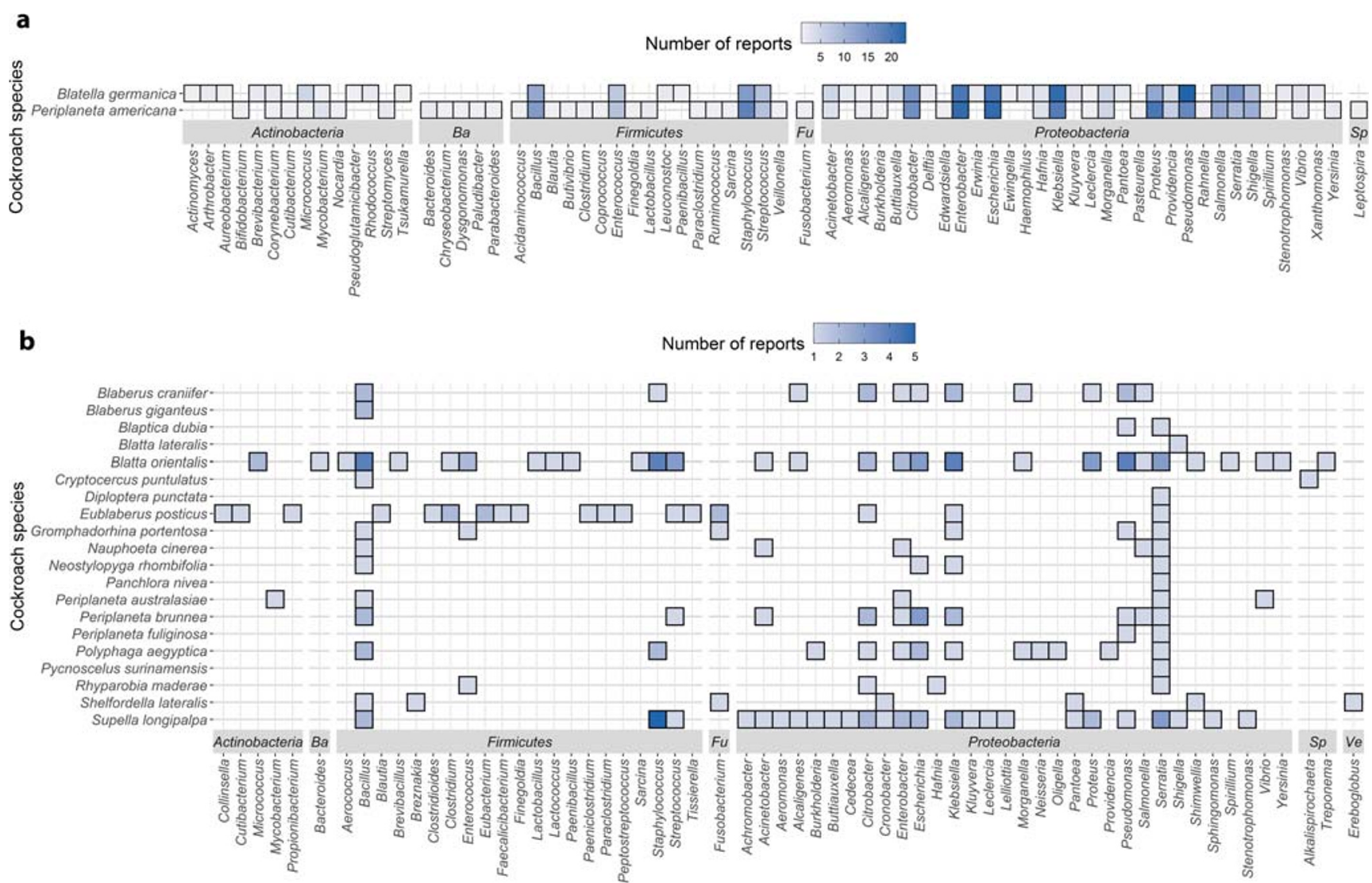

Fig. 2 Genera of bacteria cultivated from cockroaches. a Cultivated bacteria isolated from the two most widely studied cockroaches: Blatella germanica and Periplaneta americana. b Cultivated bacteria isolated from lesser-studied cockroaches. The stronger the blue color, the higher number of reports discussing the cultivation of a bacterial species from a particular cockroach. $B a, F u, S p$, and $V e$ refer to Bacteroidetes, Fusobacteria, Spirochaetes, and Verrucomicrobia, respectively. The absence of data (white boxes) does not imply the absence of a particular phylum, but rather the lack of corresponding reports 
primers, sequencing, databases, and bioinformatics pipelines) although probably to a lesser extent. Higher termite gut microbiomes were among the first insect microbial communities to be studied because of the useful ability of the microorganisms to digest wood, explained by the activity of a consortium of bacteria and archaea (Brune and Dietrich 2015). Given their phylogenetic and ecological relationship with termites, cockroach microbiomes have been the subject of various studies and broad similarities in the structure of the communities have been reported (Online Resources 3 and 4). In contrast to cultivation approaches, the major phylum according to molecular studies is Firmicutes, followed by Bacteroidetes and finally Proteobacteria, together three accounting for more than $80 \%$ of the bacterial diversity (Fig. 3a).

\section{Firmicutes}

Firmicutes is the second most frequently cultivated bacterial phylum from cockroaches (Fig. 2) but the most abundant phylum according to culture-independent methods, accounting for $\sim 50 \%$ of the bacteria in some cockroaches such as Ergaula spp. (Dietrich et al. 2014; Tinker and Ottesen 2020). Firmicutes is most abundant in the midgut ( 43\%) compared to $30 \%$ in the foregut and $34 \%$ in the hindgut (Fig. 3b, Online resource 4). Given the more alkaline nature (pH 6.1-8.9) of the midgut (Vinokurov et al. 2007), a number of alkaliphilic, aerobic bacteria of the genera Bacillus, Paenibacillus, and Enterococcus flourish there (Yumoto et al. 2011).

The genus Bacillus has been readily cultivated from cockroaches, particularly strains related to B. cereus and B. subtilis. Molecular microbiome studies demonstrated the widespread presence in cockroaches of different clades of the family Bacillaceae including Bacillus, Geobacillus, Oceanobacillus, and Ureibacillus and also other related taxa such as Paenibacillus and Lysinibacillus and several unclassified clusters (Lampert et al. 2019; Mikaelyan et al. 2015; Schauer et al. 2014). A filamentous form of B. cereus known as Arthromitus attaches not only to gut epithelial cells in the cockroaches Blaberus giganteum and Gromphadorhina portentosa but also to termites, beetles, and some crustaceans (Margulis et al. 1998). The Arthromitus form is found in healthy cockroaches, and poor diet is associated with its depletion (Feinberg et al. 1999). B. cereus and related species such as $B$. anthracis and $B$. thuringiensis can cause disease in humans and other animals including insects because these bacteria can secrete lytic enzymes and toxins (Ehling-Schulz et al. 2019). The B. cereus strain B1 isolated from Blaberus craniifer (Ratcliffe and Rowley 1984) was shown to be highly pathogenic toward the cockroach Rhyparobia maderae, and a phospholipase $\mathrm{C}$ was found to be responsible for this effect (Rahmet-Alla and Rowley 1989; Rahmet-Alla and Rowley 1990). The B. subtilis strain BGI-1 isolated from Blatte. germanica showed strong fungicidal activity against Beauveria bassiana, but the active components were not identified (Huang et al. 2013). Another Bacillus strain cultured from $P$ e. americana, identified as the isolate $29 \mathrm{~K}$, showed the strongest keratinolytic and proteolytic activity among other Bacillus strains, achieving complete feather digestion in 7 days (Sharma et al. 2019). These examples demonstrate the biotechnological potential of Bacillus from cockroaches (Table 1), particularly the production of bioactive metabolites (Um et al. 2013) and industrially valuable enzymes, and also as a platform for the production of recombinant proteins (van Dijl and Hecker 2013).

The Staphylococcus genus has been isolated from six cockroaches, and $S$. aureus is the most frequently isolated species. According to culture-independent studies, staphylococci are abundant in the hindgut of Shelfordella lateralis (Schauer et al. 2014), but less abundant in other cockroaches (Lampert et al. 2019). Although S. aureus is a commensal bacterium that asymptomatically colonizes the skin and oral mucosa of $\sim 30 \%$ of the human population, it can also gain virulence and cause dangerous infections (Gorwitz et al. 2008). The prominent presence of $S$. aureus in cockroaches has shaped the latter's reputation as a disseminator of pathogens, particularly given the isolation of antibiotic-resistant $S$. aureus strains from some hospital cockroaches (Abdolmaleki et al. 2019; Islam et al. 2016; Menasria et al. 2014b). S. aureus has also been isolated from ants, butterflies, flies, gnats, moths, and wasps from two Brazilian hospitals (Oliveira et al. 2014).

The order Lactobacillales is prevalent in cockroaches, and particularly the genera Enterococcus and Streptococcus have been cultured from Blatta orientalis, Blatte. germanica, and Pe. americana (Online Resource 2). The genus Lactobacillus has been isolated from Blatta orientalis and Pe. americana, and both homofermentative and heterofermentative classes have been reported to proliferate in the gut (Kane and Breznak 1991). In culture-independent studies, Lactobacillales were particularly abundant in the crops of the leaf litter cockroaches Ergaula capuchina and Byrsotria fumigata accounting for more than $40 \%$ of the species (Lampert et al. 2019). Interestingly, $\sim 50 \%$ of the reads from this group were assigned to unclassified taxa, including a group labeled "cockroach cluster", suggesting that there exists a particular bacterial clade uniquely present in cockroaches that should be targeted for cultivation. Enterococci and lactobacilli are common gut bacteria (Walter 2008), and although their precise role is unclear, they probably improve the digestibility of food by transforming sugars into acetate and lactate, which are readily absorbed (Kane and Breznak 1991; Moreno et al. 2006). Some enterococci are opportunistic pathogens associated with nosocomial infections (Lebreton et al. 2014), and in insects, their translocation to the hemolymph is associated with disease (Mason et al. 2011). On the other 
hand, feeding insects with enterococci or lactobacilli can prevent death caused by B. thuringiensis (Grau et al. 2017) and other entomopathogens (Arredondo et al. 2018; Daisley et al. 2017; Rossoni et al. 2018). Enterococci are known to produce bacteriocins to suppress the growth of competing bacteria (Franz et al. 2007), and because they are naturally present in many artisanal food products, they can be used in the food industry either directly as a starter culture or as a source of purified antibiotic peptides (Khan et al. 2010). For example, nisin is currently an authorized food preservative (Younes et al. 2017) for sausage, cheese, and other meat and dairy products because it is a safe, thermostable during food processing but degradable by gastric and pancreatic proteases, thus having no effect on native gut microbes. The strain Enterococcus faecalis E18 isolated from a cockroach in Nigeria was shown to produce an enterocin or mixture of bacteriocins with strong antibacterial activity (David et al. 2012). Lactobacilli isolated from the honey bee have already been proposed as alternative probiotics (Parichehreh et al. 2018) and similar concepts could be applied to lactobacilli from cockroaches.

Anoxic portions of the cockroach midgut and hindgut are home to anaerobic bacteria and in particular members of the order Clostridiales, but specialized techniques are needed to cultivate them and only a few such studies have been reported in the literature. Species of the genus Clostridium have been cultivated from Blatta orientalis (Roth and Willis 1960) and Eu. posticus and Pe. americana (Cruden and Markovetz 1987). Other genera from the order Clostridiales cultivated from cockroaches (Online Resource 2) belong to the families Clostridiaceae (Clostridium, Paeniclostridium, Paraclostridium, Sarcina), Eubacteriaceae (Eubacterium), Lachnospiraceae (Blautia, Butyrivibrio, Coprococcus), Oscillospiraceae (Faecalibacterium, Ruminococcus), Peptoniphilaceae (Finegoldia), and Peptostreptococcaceae (Clostridioides, Peptostreptococcus) (Cruden and Markovetz 1987; Cruden and Markovetz 1979; Foglesong et al. 1984). Members of two less common Firmicutes classes (Tissierellia and Erysipelotrichia) have also been cultivated from cockroaches. The species Tissierella preacuta was cultivated from Eu. posticus (Cruden and Markovetz 1987) and Breznakia blatticola was isolated from Sh. lateralis (Tegtmeier et al. 2016a). B. blatticola is an anaerobic rod-like bacterium that produces formate, ethanol, and acetate from D-glucose. Moreover, the families Lachnospiraceae and Ruminococcaceae from the order Clostridiales are particularly well represented (5-28\%) in the hindguts of all cockroaches (Lampert et al. 2019). In terms of abundance, three clusters are prominent: the gut cluster of Lachnospiraceae, and two clusters of Ruminococcaceae, one related to insects and one specific to cockroaches and termites, the latter being particularly abundant in omnivorous cockroaches (Lampert et al. 2019). The anaerobic family Peptostreptococcaceae is abundant in
Ergaula capucina (3-6\% of relative abundance), Rhyparobia maderae, Ellipthorina chopardi, and Sh. lateralis but not in other cockroaches (Lampert et al. 2019). Another moderately abundant clade of the order Clostridiales is the anaerobic or microaerophilic family Veillonellaceae $(0.5-6 \%$ relative abundance in omnivorous cockroaches and Panesthia angustipennis). Interestingly, the Veillonellaceae family has been considered as a potential source of probiotic bacteria in animal husbandry because it reduces lactic acid accumulation in the rumen, which enhances overall productivity, but also prevents the colonization of swine and chicken by pathogenic bacteria (Marchandin and Jumas-Bilak 2014). The family Christensenellaceae was defined in 2012 based on a species recovered from human feces (Morotomi et al. 2012) and is an important focus of research today because it promotes health and is considered a probiotic (Waters and Ley 2019). Members of this family have been also detected by molecular methods in Blatte. germanica (Carrasco et al. 2014; Kakumanu et al. 2018; Zhang and Yang 2019) and Diploptera punctata (Ayayee et al. 2017,) but no species have yet been cultured from cockroaches. Some Clostridium strains isolated from cockroaches can degrade carboxymethyl cellulose (Cruden and Markovetz 1979) and could be used in biorefineries and biomass conversion processes to convert inexpensive and abundant cellulose into fermentable sugars, which can be then transformed into acetic acid, acetone, butanol, ethanol, or other commodity products (Cheng et al. 2019). Two Clostridium species, one isolated from termites and one from soil, have been used together to transform cellulose into the clean fuel hydrogen (Gomez-Flores et al. 2017). Diets rich in complex carbohydrates such as bran can enhance the production of hydrogen in the cockroach gut (Schauer et al. 2014). This is probably mediated by the abundant members of the order Clostridiales, perhaps with assistance from the phylum Bacteroidetes. Acetogenesis by $\mathrm{CO}_{2^{-}}$ reduction also occurs in cockroach guts and members of the Clostridiales Lowell cluster A (Lovell and Leaphart 2005) are partly responsible for this conversion (Ottesen and Leadbetter 2010). The capture of atmospheric $\mathrm{CO}_{2}$ using such processes could help to mitigate climate change.

\section{Bacteroidetes}

Culture-independent studies indicate that the phylum Bacteroidetes is second after Firmicutes in terms of relative abundance in most cockroaches (Lampert et al. 2019), but in some species, such as house-dwelling cockroaches of the genera Periplaneta and Blattella, Bacteroidetes is often the most prominent phylum (Kakumanu et al. 2018; Rosas et al. 2018; Tinker and Ottesen, 2016). Bacteroidetes species preferably colonizes the cockroach hindgut (Fig. 3b, Online resource 4), which features anoxic and reducing conditions (Bauer et al. 2015; Lampert et al. 2019; Schauer et al. 2012). Despite their 


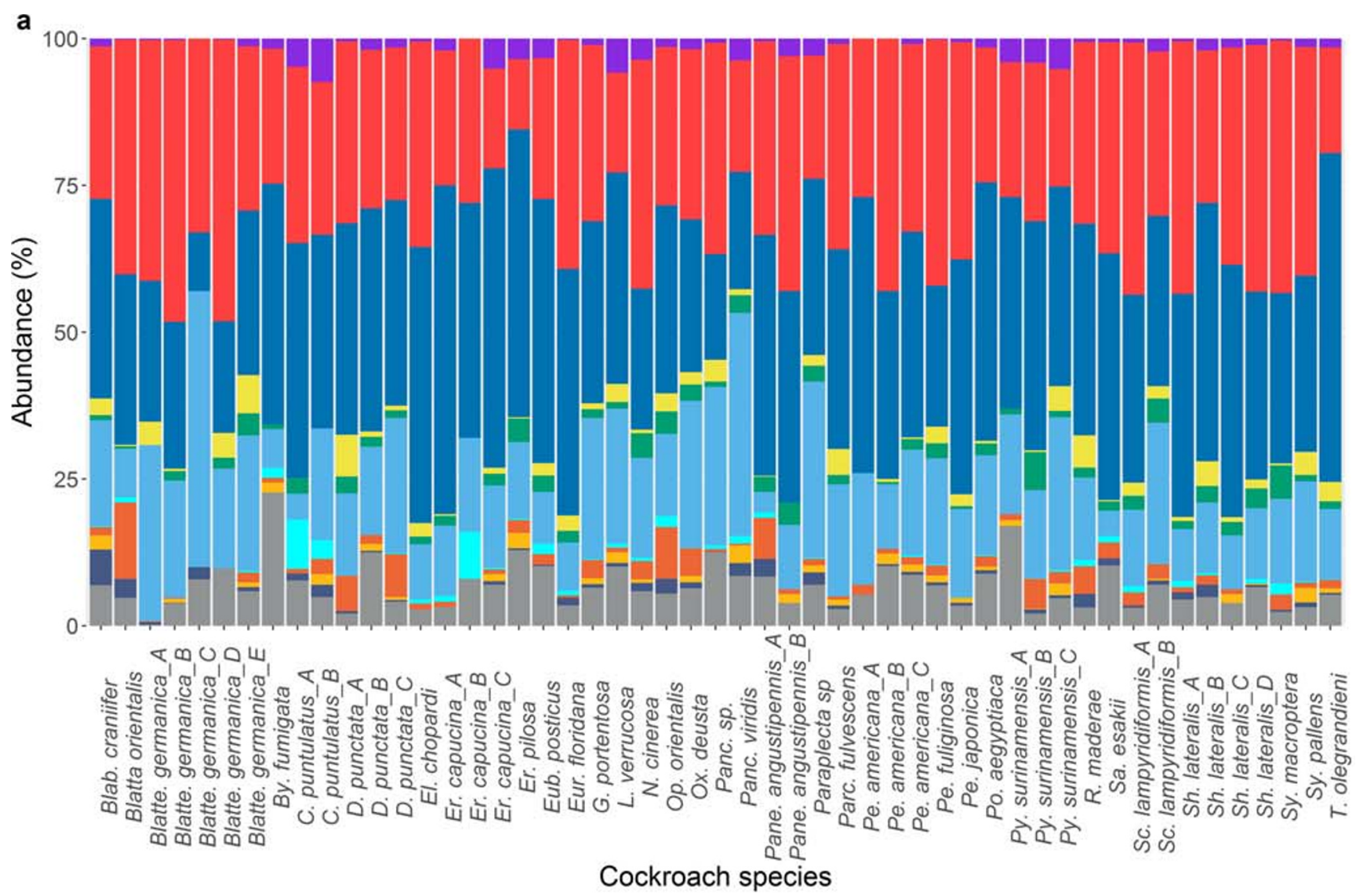
Phylum $\begin{array}{lll}\text { Actinobacteria } \\ \text { Bacteroidetes } \\ \text { Firmicutes }\end{array}-\begin{aligned} & \text { Fusobacteria } \\ & \text { Planctomycetes } \\ & \text { Proteobacteria }\end{aligned}-\begin{aligned} & \text { Spirochaetes } \\ & \text { Synergistetes } \\ & \text { Tenericutes }\end{aligned}$
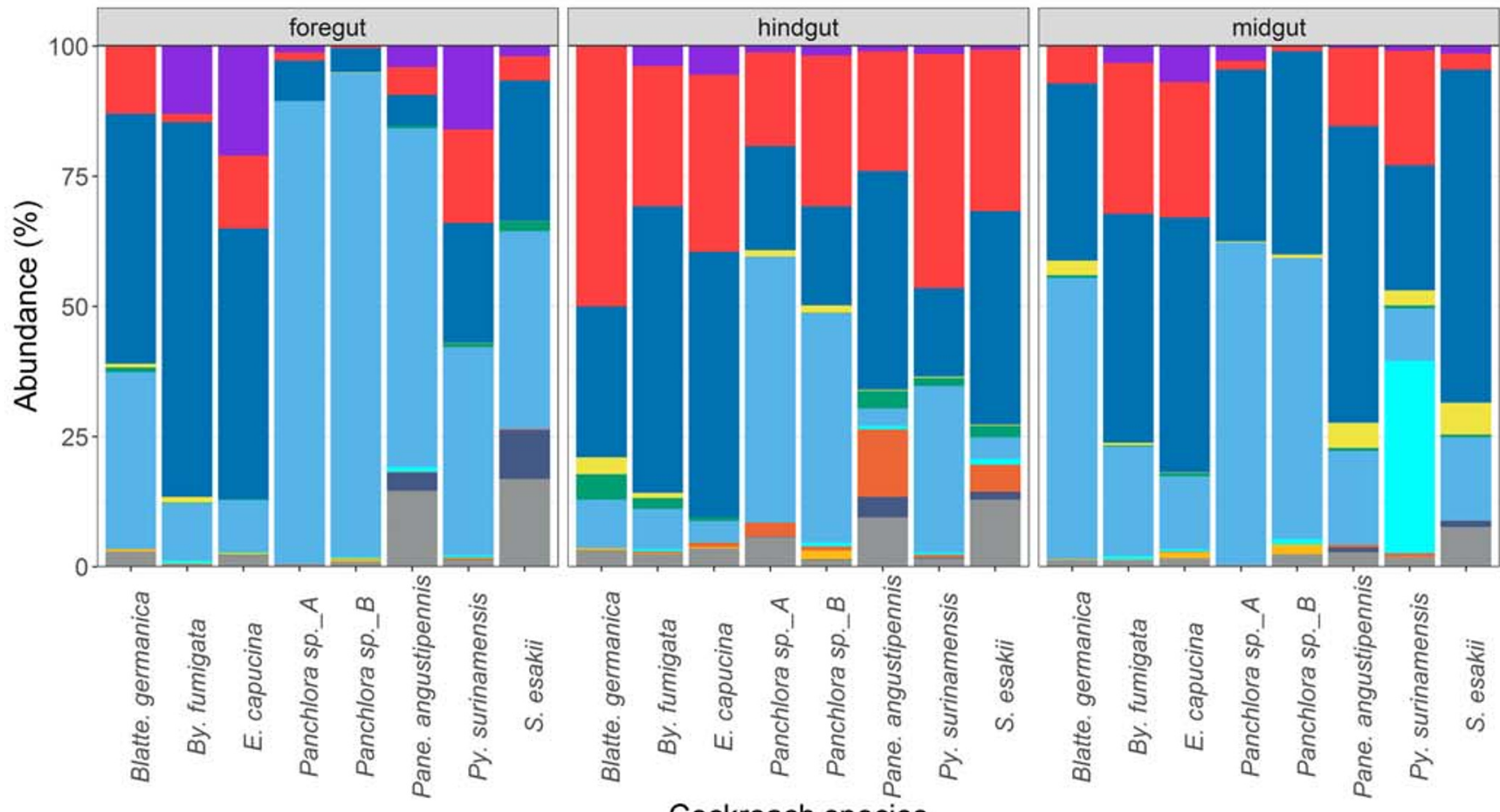

Cockroach species 
4 Fig. 3 Relative abundance of bacterial phyla identified in cockroaches. a Comprehensive summary of literature studies reporting cockroach bacterial composition by phylum. Multiple studies involving the same species of cockroach are distinguished using capital letters (see Online Resource 3). b Differences in phyla composition (phylum level) in the foregut, midgut, and hindgut compartments (see Online Resource 4)

abundance, few cockroach-derived Bacteroidetes have been cultured (Cruden and Markovetz 1987; Dugas et al. 2001; Roth and Willis 1960; Vera-Ponce de León et al. 2020) (Fig. 2, Supplementary Table 2). The Bacteroidetes are non-sporulating obligate anaerobes that can metabolize complex polysaccharides such as cellulose, chitin, pectin, and xylan (Thomas et al. 2011). The order Bacteroidales is the most abundant in cockroaches, and the most prevalent families are the Porphyromonadaceae in cockroach that feed on leaf litter and wood, and Rikenellaceae in omnivorous cockroaches (Lampert et al. 2019). Within the family Porphyromonadaceae, two clades are prominent: one related to the genus Dysgonomonas, and the other is a yet unclassified group known as the "cockroach cluster." Novel Dysgonomonas species have been isolated from termites (Pramono et al. 2015; Yang et al. 2014), and others have been recently cultured from $P e$. americana (Vera-Ponce de León et al. 2020). From the family Rikenellaceae, the most important group is the genus Alistipes, which is particularly abundant in omnivorous cockroaches, but no individual species has been isolated from cockroaches thus far. The genus Bacteroides (order Bacteroidales) is present in the midgut and hindgut of cockroaches that feed on leaf litter but has not been found in wood-feeding cockroaches (Lampert et al. 2019), suggesting these bacteria digest complex polysaccharides such as cellulose, starch, and pectin, a finding corroborated by whole-genome sequencing and in vitro assays on cockroach-derived Bacteroides, Dysgonomonas, Paludibacter, and Parabacteroides isolates (Vera-Ponce de León et al. 2020). These bacteria produce powerful degrading enzymes with potential applications in the food/feed, textiles, paper, and cosmetics industries, as well as agriculture.

A yellow Chryseobacterium strain FR2 from the order Flavobacteriales was isolated from the hindgut of $P e$. americana and cultured under anoxic conditions (Dugas et al. 2001). Given that Blattabacterium belongs to the order Flavobacteriales, extant cultivable bacteria representing this order in cockroaches are interesting because they could be intermediate forms from which Blattabacterium evolved. Moreover, Chryseobacterium species are useful in the context of industrial biotechnology because they produce flexirubin pigments (Siddaramappa et al. 2019) and hydrolytic enzymes (Brandelli and Riffel 2005; Gandhi et al. 2009).

\section{Proteobacteria}

The Proteobacteria are the most frequently cultivated bacterial phylum from cockroaches, and members of the class Gammaproteobacteria are particularly abundant. Proteobacteria are most abundant in the foregut $(\sim 48 \%)$ and less so in the midgut $(\sim 31 \%)$ and hindgut $(\sim 19 \%)$ (Fig. $3 \mathrm{~b}$, Online resource 4$)$, probably reflecting the more acidic and aerobic environment of the foregut $(\mathrm{pH} 5.0-6.8)$ which may be optimal for some clades of the phylum (Lampert et al. 2019). The order Enterobacterales (particularly the family Enterobacteriaceae) is the most abundant according to molecular studies (Lampert et al. 2019), followed by the orders Xanthomonadales and Pseudomonadales. This trend is supported by the frequency of cultivation, with the exception of Xanthomonadales which has been cultivated less often than Pseudomonadales. Serratia is the most frequently isolated genus from cockroaches (Fig. 2). There are 21 validated species of Serratia according to the List of Prokaryotic names with Standing in Nomenclature (LPSN, lpsn.dsmz.de) (Parte et al. 2020), and five of these (Serratia liquefaciens, $S$. marcescens, S. odorifera, S. plymuthica, and S. rubidaea) have been isolated (Elyasigomari et al. 2017; Menasria et al. 2014a; Pai et al. 2005; Roth and Willis 1960). However, identification in all cases was based on phenotypic and biochemical characters, which are not as precise as 16S rRNA gene sequencing. Serratia species have been found in healthy, sick, and dead insects, and they are residents of the normal insect community (Grimont and Grimont 2006; Grimont et al. 1979). They can also be opportunistic pathogens, and $S$. marcescens in particular often causes red disease in crowded colonies (Cruden and Markovetz 1979; Petersen and Tisa 2013). Chitinases and proteases secreted by $S$. marcescens are highly toxic in the insect hemocoel (Kaška et al. 1976; Lysenko 1976). Serratia entomophila is responsible for amber disease in the grass grub Costelytra zealandica mediated by the expression of plasmid-encoded Sep toxin, which inhibits the secretion of digestive enzymes (Gatehouse et al. 2009). Other Serratia species are clearly mutualistic, for example Serratia symbiotica is a cosymbiont of Buchnera aphidicola in aphids, providing essential metabolites to the host (Lamelas et al. 2011). Serratia species are known to produce specialized metabolites (Heise et al. 2019; Petersen and Tisa 2013), and given the abundance of cultured Serratia strains from cockroaches, a detailed investigation involving sequencing and the detection of biosynthetic gene clusters should be undertaken. Other members of the family Enterobacteriaceae and in particular the genera Citrobacter, Enterobacter, Escherichia, and Klebsiella have been frequently been isolated from cockroaches (Fig. 2), whereas other genera are less prominent. Although a number of these Enterobacteriaceae can be important human pathogens, there is a wide range of lifestyles and diversity in genotypes and phenotypes, and thus, 
pathogenicity cannot be inferred from taxonomy. The biotechnological applications of insect-derived Enterobacteriaceae include their ability to deliver toxic genes to pest insects (Zhang et al. 2010), their use as a source of plant-stimulating (Pan et al. 2019) and antimicrobial (Vivero et al. 2019) metabolites, and their use as in insect-rearing facilities (Augustinos et al. 2015; Azis et al. 2019). Shimwellia blattae (synonym: Escherichia blattae) was originally isolated from Blatta orientalis (Burgess et al. 1973) and later from other cockroaches (strains DSM 4481, ATCC 33429 and ATCC 33430), and interestingly, this species can synthesize cobalamin de novo and has been developed as a biotechnological source of vitamin $B_{12}$ (Andres et al. 2004; Brzuszkiewicz et al. 2012).

The genera Acinetobacter and Pseudomonas, which belong to the order Pseudomonadales, have frequently been cultured from cockroaches (Fig. 2), and culture-independent studies have also revealed they are highly abundant (relative abundance $>16 \%$ ) in the crop of Pycnoscelus surinamensis (Lampert et al. 2019). Human infections with Acinetobacter baumanii or Pseudomonas aeruginosa are difficult to treat in clinical practice due to the prevalence of antibiotic resistance, but no evidence of drug resistance was found in the $P$. aeruginosa strains isolated from cockroaches (Zarei et al. 2018). $P$. aeruginosa is the most frequently cultivated species of this genus, although cockroach-associated strains of $P$. fluorescens, $P$. putida, and $P$. reactans have also been reported (Online Resource 2). Pseudomonas species are very important in biotechnology, not only because they produce bioactive metabolites (Gross and Loper 2009) but also for their use in bioremediation (Wasi et al. 2013) and as a source of powerful lytic enzymes (proteases, lipases) for industrial processes. For example, the strains $P$. reactans BGI-14 (Zhang et al. 2013a) and P. aeruginosa BGf-2 (Zhang et al. 2020), isolated from Blatte. germanica, showed antifungal activity against the entomopathogenic fungus Beauveria bassiana. Furthermore, in culture-independent studies, the order Xanthomonadales was found to be abundant in the crops of xylophagous cockroaches Pa. angustipennis and Salganea esakii (Lampert et al. 2019), and members of this order (in particular strains of Stenotrophomonas maltophilia) have been cultured from Blatta orientalis, Blatte. germanica, and Supella longipalpa (Elgderi et al. 2006; Le Guyader et al. 1989; Mpuchane et al. 2006; Ozdal et al. 2016). The S. maltophilia OG2 isolated from Blatta orientalis was found to degrade the toxic organochlorinated pesticide endosulfan, utilizing it as a sulfur source, and transforming it to less toxic metabolites (Ozdal et al. 2017).

In addition to the Gammaproteobacteria, members of the Alphaproteobacteria, Betaproteobacteria, and to a lesser extent Deltaproteobacteria are relatively abundant in cockroaches based on cultivation-independent experiments (Lampert et al. 2019). Alphaproteobacteria are frequently identified (10-20\% relative abundance) in the crops of cockroaches that feed on leaf litter and wood, particularly unclassified members of the order Rhizobiales and the family Acetobacteraceae (order Rhodospirillales). Both clades can fix atmospheric nitrogen, but this process has not been shown to occur directly in cockroaches, although hindgut protists can carry nitrogen-fixing bacteria (Tai et al. 2016). The Acetobacteraceae family is widespread in insects (Crotti et al. 2010) and although their role is unclear, members of this clade are useful for industrial oxidation reactions (such as the production of sorbose and acetic acid), so it is possible that cockroach-derived Acetobacteraceae could be used for this application in the future. A strain of Sphingomonas paucimobilis was isolated from Su. longipalpa (Le Guyader et al. 1989), and although this bacterium is an opportunistic human pathogen associated with nosocomial infections (Ryan and Adley 2010), it has also been applied in bioremediation (Coppotelli et al. 2008) and can synthesize gellan gum (Prajapati et al. 2013). Members of the class Betaproteobacteria, particularly those from the order Burkholderiales have also been cultured from cockroaches. The genera Alcaligenes (Oligella) and Burkholderia (Fig. 2, Online Resource 2) have been isolated from Blatta orientalis, Blatte. germanica, Pe. americana, Polyphaga aegyptiaca, and Su. longipalpa (Elyasigomari et al. 2017; García et al. 2012; Le Guyader et al. 1989; Roth and Willis 1960). Burkholderia species are important insect gut symbionts fulfilling diverse functions ranging from nutrition in stinkbugs to the protection of beetle eggs via the production of antifungal secondary metabolites (Kaltenpoth and Flórez 2020), but in cockroaches, their ecological function is unknown. The order Burkholderiales is the most abundant in cockroaches, particularly in the crop of $P y$. surinamensis and $P a$. angustipennis, but the order Rhodocyclales is also frequently identified (18\% relative abundance) in the gut of Py. surinamensis (Lampert et al. 2019). Alcaligenes faecalis lives within entomopathogenic nematodes and causes damage when injected into the hemocoel of Galleria mellonella (Quiroz-Castañeda et al. 2015). Insect-derived strains of Alcaligenes demonstrated antifungal activity (Shan et al. 2019) and together with the genus Achromobacter, isolated from Su. longipalpa (Le Guyader et al. 1989), they may produce bioactive specialized metabolites in a similar way to Xenorhabdus and Photorhabdus. Finally, Deltaproteobacteria are moderately abundant in the hindgut of omnivorous cockroaches, and particularly, the orders Desulfobacterales and Desulfovibrionales (Lampert et al. 2019) are useful for biotechnological processes because they reduce sulfate to sulfide (Trinkerl et al. 1990). They have been applied to contaminated soils, reducing the bioavailability of soluble toxic cadmium, which remains insolubly complexed with sulfide (Wang et al. 2019). 


\section{Actinobacteria}

Actinobacteria is an important phylum for biotechnology, because members of the family Streptomycetaceae produce a range of specialized metabolites. This phylum is generally abundant in cockroaches (13-21\% relative abundance), although less so in species that feed on leaf litter feeding, and the orders Bifidobacteriales and Corynebacteriales are the most prevalent (Lampert et al. 2019). Actinobacteria are also found in the crop of xylophagous cockroaches but are much less abundant (1.7-4.1\%). Mycobacterium is a frequently cultivated genus (Fig. 2, Online Resource 2), and because some species are human pathogens that survive passage through the cockroach digestive system (Fischer et al. 2003), cockroaches have been linked to the dissemination of mycobacterial disease (Allen 1987; Pai et al. 2003). The genera Micrococcus, Corynebacterium, and Cutibacterium are also frequently cultured from cockroaches (Cruden and Markovetz 1987). It is interesting to note that termites are a rich source of bacteria from the family Streptomycetaceae which perform functions that protect and maintain the colony (Kurtböke et al. 2015; Sujada et al. 2014), but few species have been isolated from cockroaches. The first reported cockroach-associated Streptomyces species was found to be carried by nematodes that recurrently infect cockroaches (Hoffman 1953), but the species "Streptomyces leidnematis" was not validated and it is currently not found in any collection. The Streptomyces globisporus strain WA5-2-7 was recently cultivated from the gut of Pe. americana and was found to match the insect clade of S. albidoflavus (Cheng et al. 2015; Matarrita-Carranza et al. 2017). The antibiotics actinomycin $X 2$ and collismycin A, both with activity against methicillin-resistant $S$. aureus (MRSA), were purified from $40 \mathrm{~L}$ of S. globisporus WA5-27 culture broth (Chen et al. 2020), highlighting the biotechnological potential of cockroach-associated Streptomyces.

\section{Fusobacteria}

The phylum Fusobacteria is found mostly in the midgut of wood-feeding cockroaches, with a $2-7 \%$ relative abundance, and in the hindgut of omnivorous cockroaches, with $0.2-6.3 \%$ relative abundance (Lampert et al. 2019). Strains belonging to the genus Fusobacterium have been cultured from $E u$. posticus, G. portentosa, Pe. americana, and Sh. lateralis (Cruden and Markovetz 1987; Robertson 2007; Tegtmeier et al. 2016b). Fusobacteria are similar to Bacteroidetes (they are Gram-negative, non-sporulating, anaerobic bacteria) but they cluster in a different group based on 16S rRNA sequences (Staley and Whitman 2010). They are normal residents of the human oral cavity and the gut, but some species are pathogenic, for example, Fusobacterium necrophorum causes an oropharyngeal infection known as Lemierre's syndrome (Riordan 2007), and F. nucleatum has been linked to colon cancer (Kostic et al. 2013). F. necrophorum has been isolated from Eu. posticus (Cruden and Markovetz 1987) and this cockroach is also home to the pleomorphic species $F$. varium, which switches between rod and cocci forms during its life cycle (Foglesong et al. 1984). Fusobacteria are used in biotechnological processes for the production of succinate (McDonald and White 2019) and also as a source of interesting enzymes for bioconversion applications (Silva et al. 2019; Tang et al. 2018).

\section{Spirochaetes}

Spiral-shaped and in general anaerobic bacteria of the phylum Spirochaetes have been isolated from a few cockroaches, and specifically, the genera Leptospira (Gonzalez-Astudillo et al. 2015) and Treponema (Roth and Willis 1960) are relevant because some species from these genera are recognized human pathogens. Molecular studies have revealed that Spirochaetes are abundant in the hindgut of $C$. punctulatus (Dietrich et al. 2014) and E. capucina (Mikaelyan et al. 2015), reaching $\sim 8 \%$ of relative abundance and also in the midgut of Py. surinamensis (Lampert et al. 2019). A new genus (Alkalispirochaeta) was proposed following the isolation of the strain JC227 from the wood-eating cockroach C. punctulatus, and other alkaliphilic spirochetes were added to the genus, including one species isolated from termites (Sravanthi et al. 2016). Alkalispirochaeta cellulosivorans JC227 can degrade cellulose at high $\mathrm{pH}$ and in presence of high salt concentrations and could therefore be suitable for the bioconversion of cellulosic materials in the detergent industry (Thapa et al. 2020).

\section{Planctomycetes}

The phylum Planctomycetes is present in the hindgut of wood-feeding and omnivorous cockroaches with a relative abundance of $0.2-8.4 \%$ based on molecular studies (Lampert et al. 2019; Richards et al. 2017). Three clusters (one gut cluster and two "termite-cockroach") of the family Planctomycetaceae are the most frequently detected in cockroaches, but they have not been validly described because a cultivable strain has yet to be isolated. Planctomycetes produce diverse specialized metabolites (Graça et al. 2016), and the discovery of new species with unknown metabolic potential could lead to new applications in pharmaceutical and agrochemical industries.

\section{Verrucomicrobia}

Only a single bacterial strain from the phylum Verrucomicrobia has been cultivated from cockroaches, although the phylum is represented in wood-feeding and omnivorous cockroaches based on culture-independent studies 
(Lampert et al. 2019; Pietri et al. 2018). The microaerophilic species Ereboglobus luteus was isolated from the hindgut of Sh. lateralis (Tegtmeier et al. 2018). This bacterium can metabolize pectin, but is unable to develop in an aerobic environment. Interestingly, like almost all Verrucomicrobia isolated from insect guts, it belongs to the family Opitutaceae. Verrucomicrobia species are a major component of the degradation community in anaerobic sludge (Wang et al. 2018) and could therefore be developed for utilization in anaerobic biorefineries.

\section{Other phyla}

Other phyla are less frequently found in cockroaches, although unique clades appear to exist in some species. For example, the family Entomoplasmataceae (phylum Tenericutes) reaches $16 \%$ relative abundance in the crop of Sa. esakii (Lampert et al. 2019), although no cockroachderived species from this phylum have been cultivated. Similarly, the Candidatus Tammella genus of the phylum Synergistetes is abundant in the hindguts of Blatta orientalis and $\mathrm{Pa}$. angustipennis, although the LPSN considers this clade as part of the phylum Bacteroidetes (Parte et al. 2020), reflecting the difficulty of valid assignments in the absence of cultured strains. The genera Edaphobacter, Telmatobacter, and other less-studied clades from the phylum Acidobacteria are relatively abundant $(0.2-6 \%)$ in the crop of wood-feeding cockroaches (Lampert et al. 2019). Moreover, some uncultivated members of the small phyla Lentisphaerae, Fibrobacteres, and Elusimicrobia and the candidate phylum TM7 appear to be unique to cockroaches and termites (Lampert et al. 2019; Mikaelyan et al. 2015) and should be studied in detail not only for taxonomic description but also to assess their ecological role and their potential utilization in biotechnology.

\section{Conclusions}

Most cockroach-associated bacteria belong to the phyla Proteobacteria, Firmicutes, and Bacteroidetes, together accounting for more than $80 \%$ of the total microbiome. The remaining $20 \%$ comprises less-abundant phyla such as Actinobacteria, Fusobacteria, Planctomycetes, Verrucomicrobia, and Spirochaetes. Among the readily cultivable bacteria from cockroaches, most studies have focused on the isolation of Gram-negative coliforms, staphylococci, and mycobacteria, and as a consequence, cockroaches have been proclaimed as unsanitary pests that pose a risk to health. Indeed, cockroaches can disseminate pathogens in their feces and should be eradicated from food preparation areas and healthcare settings. However, we consider cockroaches as a promising source of biotechnologically useful microorganisms, because they have co-evolved with bacteria, which are therefore likely to produce less toxic antimicrobials compared to soil bacteria in order to ensure the host survives. Cockroach-derived bacteria also appear to be easier to cultivate than bacteria associated with termites. Recent research has revealed the presence of less-explored taxa that could improve our understanding of microbe-host relationships and perhaps more importantly expand the biotechnological applications of microorganisms in biorefineries, bioremediation, and the development of pharmaceutical and agrochemical products and industrial enzymes.

Authors' contributions JG performed the literature search, collected the data in tables, prepared the figures, and wrote the first draft. AV corrected inaccuracies and improved the quality and readability of the manuscript.

Funding Open Access funding enabled and organized by Projekt DEAL. The authors received funding from the Hessen State Ministry of Higher Education, Research and the Arts (HMWK) through the collaborative research projects granted under the LOEWE Centers for "Insect Biotechnology and Bioresources." JG received support from the Alexander von Humboldt Foundation via a Georg Forster research fellowship.

Data availability Not applicable.

\section{Compliance with ethical standards}

Conflict of interest The authors declare that they have no conflict of interest.

Ethics approval Not applicable.

Consent to participate Not applicable.

Consent for publication Not applicable.

Code availability Not applicable.

Open Access This article is licensed under a Creative Commons Attribution 4.0 International License, which permits use, sharing, adaptation, distribution and reproduction in any medium or format, as long as you give appropriate credit to the original author(s) and the source, provide a link to the Creative Commons licence, and indicate if changes were made. The images or other third party material in this article are included in the article's Creative Commons licence, unless indicated otherwise in a credit line to the material. If material is not included in the article's Creative Commons licence and your intended use is not permitted by statutory regulation or exceeds the permitted use, you will need to obtain permission directly from the copyright holder. To view a copy of this licence, visit http://creativecommons.org/licenses/by/4.0/.

\section{References}

Abdolmaleki Z, Mashak Z, Safarpoor Dehkordi F (2019) Phenotypic and genotypic characterization of antibiotic resistance in the methicillinresistant Staphylococcus aureus strains isolated from hospital 
cockroaches. Antimicrob Resist Infect Control 8(1):54. https://doi. org/10.1186/s13756-019-0505-7

Akinjogunla OJ, Odeyemi A, Udoinyang E (2012) Cockroaches (Periplaneta americana and Blattella germanica): reservoirs of multi drug resistant (MDR) bacteria in Uyo, Akwa Ibom State. Sci J Biol Sci 1(2):19

Ali SM, Siddiqui R, Ong S-K, Shah MR, Anwar A, Heard PJ, Khan NA (2017) Identification and characterization of antibacterial compound (s) of cockroaches (Periplaneta americana). Appl Microbiol Biotechnol 101(1):253-286. https://doi.org/10.1007/s00253-016$7872-2$

Allen BW (1987) Excretion of viable tubercle bacilli by Blatta orientalis (the oriental cockroach) following ingestion of heat-fixed sputum smears: a laboratory investigation. Trans R Soc Trop Med Hyg 81(1):98-99. https://doi.org/10.1016/0035-9203(87)90295-1

Andres S, Wiezer A, Bendfeldt H, Waschkowitz T, Toeche-Mittler C, Daniel R (2004) Insights into the genome of the enteric bacterium Escherichia blattae: cobalamin (B12) biosynthesis, B12-dependent reactions, and inactivation of the gene region encoding $\mathrm{B} 12$ dependent glycerol dehydratase by a new mu-like prophage. J Mol Microbiol Biotechnol 8(3):150-168. https://doi.org/10.1159/ 000085788

Arredondo D, Castelli L, Porrini MP, Garrido PM, Eguaras MJ, Zunino P, Antúnez K (2018) Lactobacillus kunkeei strains decreased the infection by honey bee pathogens Paenibacillus larvae and Nosema ceranae. Benef microbes 9(2):279-290. https://doi.org/10. 3920/bm2017.0075

Ash N, Greenberg B (1980) Vector potential of the German cockroach (Dictyoptera: Blattellidae) in dissemination of Salmonella enteritidis serotype Typhimurium. J Med Entomol 17(5):417-423. https://doi.org/10.1093/jmedent/17.5.417

Augustinos AA, Kyritsis GA, Papadopoulos NT, Abd-Alla AM, Cáceres C, Bourtzis K (2015) Exploitation of the medfly gut microbiota for the enhancement of sterile insect technique: use of Enterobacter sp. in larval diet-based probiotic applications. PLoS One 10(9): e0136459. https://doi.org/10.1371/journal.pone.0136459

Ayayee PA, Keeney G, Sabree ZL, Muñoz-Garcia A (2017) Compositional differences among female-associated and embryoassociated microbiota of the viviparous pacific beetle cockroach, Diploptera punctata. FEMS Microbiol Ecol 93(6):fix052. https:// doi.org/10.1093/femsec/fix052

Azis K, Zerva I, Melidis P, Caceres C, Bourtzis K, Ntougias S (2019) Biochemical and nutritional characterization of the medfly gut symbiont Enterobacter sp. AA26 for its use as probiotics in sterile insect technique applications. BMC Biotechnol 19(2):1-10. https://doi. org/10.1186/s12896-019-0584-9

Basseri HR, Dadi-Khoeni A, Bakhtiari R, Abolhassani M, HajihosseiniBaghdadabadi R (2016) Isolation and purification of an antibacterial protein from immune induced haemolymph of American cockroach, Periplaneta americana. J Arthropod-Borne Dis 10(4):519

Bauer E, Lampert N, Mikaelyan A, Köhler T, Maekawa K, Brune A (2015) Physicochemical conditions, metabolites and community structure of the bacterial microbiota in the gut of wood-feeding cockroaches (Blaberidae: Panesthiinae). FEMS Microbiol Ecol 91(2):1-14. https://doi.org/10.1093/femsec/fiu028

Beccaloni GW (2014) Cockroach species file online. Publisher. http:// cockroach.speciesfile.org/ accessed 06.01.2020 2020

Beemelmanns C, Guo H, Rischer M, Poulsen M (2016) Natural products from microbes associated with insects. Beilstein J Org Chem 12(1): 314-327. https://doi.org/10.3762/bjoc. 12.34

Bell WJ, Roth LM, Nalepa CA, Wilson EO (2007) Cockroaches: ecology, behavior, and natural history. Johns Hopkins University Press, $p$ 248

Bouamamaa L, Sorlozano A, Laglaoui A, Lebbadi M, Aarab A, Gutierrez J (2010) Antibiotic resistance patterns of bacterial strains isolated from Periplaneta americana and Musca domestica in Tangier,
Morocco. J Infect Dev Countr 4(4):194-201. https://doi.org/10. 3855/jidc.336

Brandelli A, Riffel A (2005) Production of an extracellular keratinase from Chryseobacterium sp. growing on raw feathers. Electron J Biotechnol 8:35-42. https://doi.org/10.2225/vol8-issue1-fulltext-6

Brooks MA (1970) Comments on the classification of intracellular symbiotes of cockroaches and a description of the species. J Invertebr Pathol 16(2):249-258. https://doi.org/10.1016/0022-2011(70) 90066-2

Brooks MA, Richards K (1966) On the in vitro culture of intracellular symbiotes of cockroaches. J Invertebr Pathol 8(2):150-157. https:// doi.org/10.1016/0022-2011(66)90123-6

Brune A, Dietrich C (2015) The gut microbiota of termites: digesting the diversity in the light of ecology and evolution. Ann Rev Microbiol 69:145-166. https://doi.org/10.1146/annurev-micro-092412155715

Brzuszkiewicz E, Waschkowitz T, Wiezer A, Daniel R (2012) Complete genome sequence of the B12-producing Shimwellia blattae strain DSM 4481, isolated from a cockroach. J Bacteriol 194(16):44364436. https://doi.org/10.1128/JB.00829-12

Burgess N, McDermott S, Whiting J (1973) Aerobic bacteria occurring in the hind-gut of the cockroach, Blatta orientalis. Epidemiol Infect 71(1):1-7. https://doi.org/10.1017/s0022172400046155

Carrasco P, Pérez-Cobas AE, Van de Pol C, Baixeras J, Moya A, Latorre A (2014) Succession of the gut microbiota in the cockroach Blattella germanica. Int Microbiol 17(2):99-109. https://doi.org/10.2436/20. 1501.01 .212

Chen Z, Ou P, Liu L, Jin X (2020) Anti-MRSA activity of actinomycin X2 and collismycin a produced by Streptomyces globisporus WA52-37 from the intestinal tract of American cockroach (Periplaneta americana). Front Microbiol 11:555. https://doi.org/10.3389/fmicb. 2020.00555

Cheng K, Rong X, Pinto-Tomás AA, Fernández-Villalobos M, MurilloCruz C, Huang Y (2015) Population genetic analysis of Streptomyces albidoflavus reveals habitat barriers to homologous recombination in the diversification of streptomycetes. App Environ Microbiol 81(3):966-975. https://doi.org/10.1128/aem. 02925-14

Cheng C, Bao T, Yang S-T (2019) Engineering Clostridium for improved solvent production: recent progress and perspective. App Microbiol Biotechnol 103(14):5549-5566. https://doi.org/10.1007/s00253019-09916-7

Clot J, Vago C (1970) Recherches sur le passage de bacteries pathogenes pour les invertebres et les vertebres (homme, animal), a travers le tube digestif de dictyopteres disseminateurs (experiences sur Blabera fusca). Ann Rech Vet 1(1):31-40

Coppotelli BM, Ibarrolaza A, Del Panno MT, Morelli IS (2008) Effects of the inoculant strain Sphingomonas paucimobilis 20006FA on soil bacterial community and biodegradation in phenanthrenecontaminated soil. Microb Ecol 55(2):173-183. https://doi.org/10. 1007/s00248-007-9265-7

Cotton MF, Wasserman E, Pieper CH, Theron DC, Dv T, Campbell G, Fang FC, Barnes J (2000) Invasive disease due to extended spectrum beta-lactamase-producing Klebsiella pneumoniae in a neonatal unit: the possible role of cockroaches. J Hosp Infect 44(1):13-17. https:// doi.org/10.1053/jhin.1999.0650

Crotti E, Rizzi A, Chouaia B, Ricci I, Favia G, Alma A, Sacchi L, Bourtzis K, Mandrioli M, Cherif A (2010) Acetic acid bacteria, newly emerging symbionts of insects. Appl Environ Microbiol 76(21):6963-6970. https://doi.org/10.1128/aem.01336-10

Cruden DL, Markovetz A (1979) Carboxymethyl cellulose decomposition by intestinal bacteria of cockroaches. Appl Environ Microbiol 38(3):369-372

Cruden DL, Markovetz A (1987) Microbial ecology of the cockroach gut. Ann Rev Microbiol 41(1):617-643. https://doi.org/10.1146/ annurev.mi.41.100187.003153 
Daisley BA, Trinder M, McDowell TW, Welle H, Dube JS, Ali SN, Leong HS, Sumarah MW, Reid G (2017) Neonicotinoid-induced pathogen susceptibility is mitigated by Lactobacillus plantarum immune stimulation in a Drosophila melanogaster model. Sci Rep 7(1):2703. https://doi.org/10.1038/s41598-017-02806-w

David OM, Oluduro AO, Famurewa O (2012) Property and antibacterial spectrum of partially purified enterocin produced by entrocinogenic Enterococcus faecalis isolated from the gut of cockroach. AU Journal of Technology 16(2):74-80

Dettner K, Peters W (2010) Lehrbuch der Entomologie, vol 2. Spektrum Akademischer Verlag, Springer, Heidelberg

Dietrich C, Köhler T, Brune A (2014) The cockroach origin of the termite gut microbiota: patterns in bacterial community structure reflect major evolutionary events. Appl Environ Microbiol 80(7):2261-2269. https://doi.org/10.1128/aem.04206-13

Donkor ES (2019) Nosocomial pathogens: an in-depth analysis of the vectorial potential of cockroaches. Trop Med Infect Dis 4(1):14. https://doi.org/10.3390/tropicalmed4010014

Dugas J, Zurek L, Paster B, Keddie B, Leadbetter E (2001) Isolation and characterization of a Chryseobacterium strain from the gut of the American cockroach, Periplaneta americana. Arch Microbiol 175(4):259-262. https://doi.org/10.1007/s002030000243

Ehling-Schulz M, Koehler TM, Lereclus D (2019) The Bacillus cereus group: Bacillus species with pathogenic potential. Microbiol Spectr 7(3):0032. https://doi.org/10.1128/microbiolspec.GPP3-0032-2018

Elgderi R, Ghenghesh K, Berbash N (2006) Carriage by the German cockroach (Blattella germanica) of multiple-antibiotic-resistant bacteria that are potentially pathogenic to humans, in hospitals and households in Tripoli, Libya. Ann Trop Med Parasitol 100(1):5562. https://doi.org/10.1179/136485906X78463

Elyasigomari A, Keshavarzi D, Ahmed Yusuf M, Hassanzadeh A, Marvi N, Shahriari-Namadi M, Nassiri Z (2017) Isolation of bacteria from the digestive tract of Periplaneta americana and Polyphaga aegyptiaca (Blattodea: Blattidae) in Khuzestan Province, Southwestern Iran. Orient Insects 51(4):345-352. https://doi.org/ 10.1080/00305316.2017.1311811

Fakoorziba MR, Shahriari-Namadi M, Moemenbellah-Fard MD, Hatam GR, Azizi K, Amin M, Motevasel M (2014) Antibiotics susceptibility patterns of bacteria isolated from American and German cockroaches as potential vectors of microbial pathogens in hospitals. Asian Pac J Trop Dis 4:S790-S794. https://doi.org/10.1016/ S2222-1808(14)60728-3

Feinberg L, Jorgensen J, Haselton A, Pitt A, Rudner R, Margulis L (1999) Arthromitus (Bacillus cereus) symbionts in the cockroach Blaberus giganteus: dietary influences on bacterial development and population density. Symbiosis 27(2):109-123

Feng Y, Chen X-M, Zhao M, He Z, Sun L, Wang C-Y, Ding W-F (2018) Edible insects in China: utilization and prospects. Insect Sci 25(2): 184-198. https://doi.org/10.1111/1744-7917.12449

Fischer OA, Matlova L, Dvorska L, Svastova P, Pavlik I (2003) Nymphs of the oriental cockroach (Blatta orientalis) as passive vectors of causal agents of avian tuberculosis and paratuberculosis. Med Vet Entomol 17(2):145-150. https://doi.org/10.1046/j.1365-2915.2003. 00417.x

Foglesong M, Cruden D, Markovetz A (1984) Pleomorphism of fusobacteria isolated from the cockroach hindgut. J Bacteriol 158(2):474-480

Fotedar R, Banerjee U (1993) Vector potential of the German cockroach in dissemination of Pseudomonas aeruginosa. J Hosp Infect 23(1): 55-59. https://doi.org/10.1016/0195-6701(93)90131-i

Fotedar R, Shriniwas UB, Verma A (1991) Cockroaches (Blattella germanica) as carriers of microorganisms of medical importance in hospitals. Epidemiol Infect 107(1):181-187. https://doi.org/10. 1017/s0950268800048809

Franz CMAP, Van Belkum MJ, Holzapfel WH, Abriouel H, Gálvez A (2007) Diversity of enterococcal bacteriocins and their grouping in a new classification scheme. FEMS Microbiol Rev 31(3):293-310. https://doi.org/10.1111/j.1574-6976.2007.00064.x

Gandhi P, Narayanan KB, Naik PR (2009) Characterization of Chryseobacterium aquaticum strain PUPC1 producing a novel antifungal protease from rice rhizosphere soil. J Microbiol Biotechnol 19(1):99-107. https://doi.org/10.4014/jmb.0803.173

Gao Y, Wang D, Xu M-L, Shi S-S, Xiong J-F (2018) Toxicological characteristics of edible insects in China: a historical review. Food Chem Toxicol 119:237-251. https://doi.org/10.1016/j.fct.2018.04. 016

García F, Notario M, Cabanás J, Jordano R, Medina L (2012) Incidence of bacteria of public health interest carried by cockroaches in different food-related environments. J Med Entomol 49(3):1481-1484. https://doi.org/10.1603/me12007

Gatehouse HS, Tan B, Christeller JT, Hurst MRH, Marshall SDG, Jackson TA (2009) Phenotypic changes and the fate of digestive enzymes during induction of amber disease in larvae of the New Zealand grass grub (Costelytra zealandica). J Invertebr Pathol 101(3):215-221. https://doi.org/10.1016/j.jip.2009.05.010

Gliniewicz A, Czajka E, Laudy A, Kochman M, Grzegorzak K, Ziółkowska K, Sawicka B, Stypulkowska-Misiurewicz H, Pancer K (2003) German cockroaches (Blattella germanica L.) as a potential source of pathogens causing nosocomial infections. Indoor Built Environ 12(1-2):55-60

Gomez-Flores M, Nakhla G, Hafez H (2017) Hydrogen production and microbial kinetics of Clostridium termitidis in mono-culture and coculture with Clostridium beijerinckii on cellulose. AMB Express 7(1):84. https://doi.org/10.1186/s13568-016-0256-2

Gonzalez-Astudillo V, Bustamante-Rengifo JA, Bonilla Á, Lehmicke AJJ, Castillo A, Astudillo-Hernández M (2015) Synanthropic cockroaches (Blattidae: Periplaneta spp.) harbor pathogenic Leptospira in Colombia. J Med Entomol 53(1):177-182. https://doi.org/10. 1093/jme/tjv172

Gorwitz RJ, Kruszon-Moran D, McAllister SK, McQuillan G, McDougal LK, Fosheim GE, Jensen BJ, Killgore G, Tenover FC, Kuehnert MJ (2008) Changes in the prevalence of nasal colonization with Staphylococcus aureus in the United States, 2001-2004. J Infect Dis 197(9):1226-1234. https://doi.org/10.1086/533494

Graça AP, Calisto R, Lage OM (2016) Planctomycetes as novel source of bioactive molecules. Front Microbiol 7:1241. https://doi.org/10. 3389/fmicb.2016.01241

Graffar M, Mertens S (1950) Le role des blattes dans la transmission des salmonelloses. Ann Inst Pasteur Microbiol 79(5):654-660

Grau T, Vilcinskas A, Joop G (2017) Probiotic Enterococcus mundtii isolate protects the model insect Tribolium castaneum against Bacillus thuringiensis. Front Microbiol 8:1261. https://doi.org/10. 3389/fmicb.2017.01261

Grimont F, Grimont PAD (2006) The genus Serratia. In: Dworkin M, Falkow S, Rosenberg E, Schleifer K-H, Stackebrandt E (eds) The prokaryotes, Proteobacteria: gamma subclass, vol 6. Springer New York, New York, pp 219-244

Grimont PAD, Grimont F, Lysenko O (1979) Species and biotype identification of Serratia strains associated with insects. Curr Microbiol 2(3):139-142. https://doi.org/10.1007/BF02605870

Gross H, Loper JE (2009) Genomics of secondary metabolite production by Pseudomonas spp. Nat Prod Rep 26(11):1408-1446. https://doi. org $/ 10.1039 / \mathrm{b} 817075 \mathrm{~b}$

Heise P, Liu Y, Degenkolb T, Vogel H, Schäberle TF, Vilcinskas A (2019) Antibiotic-producing beneficial bacteria in the gut of the burying beetle Nicrophorus vespilloides. Front Microbiol 10:1178. https://doi.org/10.3389/fmicb.2019.01178

Hoffman GL (1953) Streptomyces leidnematis n. sp., growing on two species of nematodes of the cockroach. Trans Am Microsc Soc 72(4):376-378. https://doi.org/10.2307/3223487

Hornig MK, Haug C, Schneider JW, Haug JT (2018) Evolution of reproductive strategies in dictyopteran insects-clues from ovipositor 
morphology of extinct roachoids. Acta Palaeontol Pol 63(1):1-24. https://doi.org/10.4202/app.00324.2016

Hornung BV, Zwittink RD, Kuijper EJ (2019) Issues and current standards of controls in microbiome research. FEMS Microbiol Ecol 95(5):fiz045. https://doi.org/10.1093/femsec/fiz045

Huang YH, Wang XJ, Zhang F, Huo XB, Fu RS, Liu JJ, Sun WB, Kang DM, Jing X (2013) The identification of a bacterial strain BGI-1 isolated from the intestinal flora of Blattella germanica, and its antientomopathogenic fungi activity. J Econ Entomol 106(1):43-49. https://doi.org/10.1603/ec12120

Imamura S, Kita M, Yamaoka Y, Yamamoto T, Ishimaru A, Konishi H, Wakabayashi N, Mitsufuji S, Okanoue T, Imanishi J (2003) Vector potential of cockroaches for Helicobacter pylori infection. Am J Gastroenterol 98(7):1500-1503. https://doi.org/10.1111/j.15720241.2003.07516.x

Islam A, Nath AD, Islam K, Islam S, Chakma S, Hossain MB, Al-Faruq A, Hassan MM (2016) Isolation, identification and antimicrobial resistance profile of Staphylococcus aureus in cockroaches (Periplaneta americana). J Adv Vet Anim Res 3(3):221-228

Kakumanu ML, Maritz JM, Carlton JM, Schal C (2018) Overlapping community compositions of gut and fecal microbiomes in labreared and field-collected German cockroaches. Appl Environ Microbiol 84(17):e01037-e01018. https://doi.org/10.1128/aem. 01037-18

Kaltenpoth M, Flórez LV (2020) Versatile and dynamic symbioses between insects and Burkholderia bacteria. Annu Rev Entomol 65(1): 145-170. https://doi.org/10.1146/annurev-ento-011019-025025

Kane MD, Breznak JA (1991) Effect of host diet on production of organic acids and methane by cockroach gut bacteria. Appl Environ Microbiol 57(9):2628-2634

Kaška M, Lysenko O, Chaloupka J (1976) Exocellular proteases of Serratia marcescens and their toxicity to larvae of Galleria mellonella. Folia Microbiol 21(6):465-473. https://doi.org/10. 1007/BF02876938

Khan H, Flint S, Yu P-L (2010) Enterocins in food preservation. Int J Food Microbiol 141(1-2):1-10. https://doi.org/10.1016/j. ijfoodmicro.2010.03.005

Kim I-W, Lee JH, Subramaniyam S, Yun E-Y, Kim I, Park J, Hwang JS (2016) De novo transcriptome analysis and detection of antimicrobial peptides of the American cockroach Periplaneta americana (Linnaeus). PLoS One 11(5):e0155304. https://doi.org/10.1371/ journal.pone. 0155304

Klowden MJ, Greenberg B (1977) Salmonella in the American cockroach: outcome of natural invasion of the hemocele. J Med Entomol 14(3):362-366. https://doi.org/10.1093/jmedent/14.3.362

Kostic AD, Chun E, Robertson L, Glickman JN, Gallini CA, Michaud M, Clancy TE, Chung DC, Lochhead P, Hold GL (2013) Fusobacterium nucleatum potentiates intestinal tumorigenesis and modulates the tumor-immune microenvironment. Cell Host Microbe 14(2):207-215. https://doi.org/10.1016/j.chom.2013.07. 007

Kui W, Ying F, Long SUN, Zhao HE, Zhi-yong C (2013) Isolation of ethyl acetate extract from Periplaneta americana and its antimicrobial activity. Forest Res 26(2):163-166

Kurtböke Dİ, French JRJ, Hayes RA, Quinn RJ (2015) Eco-taxonomic insights into actinomycete symbionts of termites for discovery of novel bioactive compounds. In: Mukherjee J (ed) Biotechnological applications of biodiversity. Springer, Berlin Heidelberg, Berlin, Heidelberg, pp 111-135

Lamelas A, Gosalbes MJ, Manzano-Marín A, Peretó J, Moya A, Latorre A (2011) Serratia symbiotica from the aphid Cinara cedri: a missing link from facultative to obligate insect endosymbiont. PLoS Genet 7(11):e1002357. https://doi.org/10.1371/journal.pgen. 1002357

Lampert N, Mikaelyan A, Brune A (2019) Diet is not the primary driver of bacterial community structure in the gut of litter-feeding cockroaches. BMC Microbiol 19(1):238. https://doi.org/10.1186/ s12866-019-1601-9

Latifi M, Alikhani MY, Salehzadeh A, Nazari M, Bandani AR, Zahirnia AH (2015) The antibacterial effect of American cockroach hemolymph on the nosocomial pathogenic bacteria. Avicenna J Clin Microbiol Infect 2(1):23017. https://doi.org/10.17795/ajcmi-23017

Le Guyader A, Rivault C, Chaperon J (1989) Microbial organisms carried by brown-banded cockroaches in relation to their spatial distribution in a hospital. Epidemiol Infect 102(3):485-492. https://doi.org/10. 1017/s095026880003020x

Lebreton F, Willems RJ, Gilmore MS (2014) Enterococcus diversity, origins in nature, and gut colonization. In: Enterococci: from commensals to leading causes of drug resistant infection [Internet]. Massachusetts Eye and Ear Infirmary. Gilmore MS, Clewell DB, Ike Y, et al., editors. Boston

Lee B, Hwang JS, Lee DG (2019) Induction of apoptosis-like death by periplanetasin-2 in Escherichia coli and contribution of SOS genes. Appl Microbiol Biotechnol 103(3):1417-1427. https://doi.org/10. 1007/s00253-018-9561-9

Legendre F, Nel A, Svenson GJ, Robillard T, Pellens R, Grandcolas P (2015) Phylogeny of Dictyoptera: dating the origin of cockroaches, praying mantises and termites with molecular data and controlled fossil evidence. PLoS One 10(7):e0130127. https://doi.org/10.1371/ journal.pone. 0130127

Lovell CR, Leaphart AB (2005) Community-level analysis: key genes of CO2-reductive acetogenesis methods in enzymology, vol 397. Academic Press, pp 454-469

Lysenko O (1976) Chitinase of Serratia marcescens and its toxicity to insects. J Invertebr Pathol 27(3):385-386. https://doi.org/10.1016/ 0022-2011(76)90101-4

Marchandin H, Jumas-Bilak E (2014) The family Veillonellaceae. In: Rosenberg E, DeLong EF, Lory S, Stackebrandt E, Thompson F (eds) The prokaryotes: Firmicutes and Tenericutes. Springer, Berlin Heidelberg, Berlin, Heidelberg, pp 433-453

Margulis L, Jorgensen JZ, Dolan S, Kolchinsky R, Rainey FA, Lo S-C (1998) The Arthromitus stage of Bacillus cereus: intestinal symbionts of animals. Proc Natl Acad Sci U S A 95(3):1236-1241. https:// doi.org/10.1073/pnas.95.3.1236

Mason KL, Stepien TA, Blum JE, Holt JF, Labbe NH, Rush JS, Raffa KF, Handelsman J (2011) From commensal to pathogen: translocation of Enterococcus faecalis from the midgut to the hemocoel of Manduca sexta. mBio 2(3):e00065-e00011. https://doi.org/10. 1128/mBio.00065-11

Matarrita-Carranza B, Moreira-Soto RD, Murillo-Cruz C, Mora M, Currie CR, Pinto-Tomas AA (2017) Evidence for widespread associations between neotropical hymenopteran insects and Actinobacteria. Front Microbiol 8:2016. https://doi.org/10.3389/ fmicb.2017.02016

McDonald NC, White RL (2019) Reduction of fumarate to succinate mediated by Fusobacterium varium. Appl Biochem Biotechnol 187(1):163-175. https://doi.org/10.1007/s12010-018-2817-0

Menasria T, Moussa F, El-Hamza S, Tine S, Megri R, Chenchouni H (2014a) Bacterial load of German cockroach (Blattella germanica) found in hospital environment. Pathog Glob Health 108(3):141147. https://doi.org/10.1179/2047773214Y.0000000136

Menasria T, Tine S, Souad E, Mahcene D, Moussa F, Benammar L, Mekahlia MN (2014b) A survey of the possible role of German cockroaches as a source for bacterial pathogens. J Adv Sci Appl Eng 1(1):67-70

Menasria T, Tine S, Mahcene D, Benammar L, Megri R, Boukoucha M, Debabza M (2015) External bacterial flora and antimicrobial susceptibility patterns of Staphylococcus spp. and Pseudomonas spp. isolated from two household cockroaches, Blattella germanica and Blatta orientalis. Biomed Environ Sci 28(4):316-320. https://doi. org/10.3967/bes2015.045 
Mikaelyan A, Köhler T, Lampert N, Rohland J, Boga H, Meuser K, Brune A (2015) Classifying the bacterial gut microbiota of termites and cockroaches: a curated phylogenetic reference database (DictDb). Syst Appl Microbiol 38(7):472-482. https://doi.org/10. 1016/j.syapm.2015.07.004

Moreno MF, Sarantinopoulos P, Tsakalidou E, De Vuyst L (2006) The role and application of enterococci in food and health. Int J Food Microbiol 106(1):1-24. https://doi.org/10.1016/j.ijfoodmicro.2005. 06.026

Morotomi M, Nagai F, Watanabe Y (2012) Description of Christensenella minuta gen. nov., sp. nov., isolated from human faeces, which forms a distinct branch in the order Clostridiales, and proposal of Christensenellaceae fam. nov. Int J Syst Evol Microbiol 62(1):144-149. https://doi.org/10.1099/ijs.0.026989-0

Moya A, Peretó J, Gil R, Latorre A (2008) Learning how to live together: genomic insights into prokaryote-animal symbioses. Nat Rev Genet 9(3):218. https://doi.org/10.1038/nrg2319

Mpuchane S, Matsheka IM, Gashe BA, Allotey J, Murindamombe G, Mrema N (2006) Microbiological studies of cockroaches from three localities in Gaborone, Botswana. Afr J Food Agric Nutr Dev 6(2): $1-17$

Nalepa C, Bignell D, Bandi C (2001) Detritivory, coprophagy, and the evolution of digestive mutualisms in Dictyoptera. Insect Soc 48(3): 194-201. https://doi.org/10.1007/PL00001767

Oliveira PS, Souza SG, Campos GB, da Silva DCC, Sousa DS, Araújo SPF, Ferreira LP, Santos VM, Amorim AT, Santos AMOG, Timenetsky J, Cruz MP, Yatsuda R, Marques LM (2014) Isolation, pathogenicity and disinfection of Staphylococcus aureus carried by insects in two public hospitals of Vitória da Conquista, Bahia, Brazil. Braz J Infect Dis 18(2):129-136. https://doi.org/10. 1016/j.bjid.2013.06.008

Oothuman P, Jeffery J, Aziz AHA, Bakar EA, Jegathesan M (1989) Bacterial pathogens isolated from cockroaches trapped from paediatric wards in peninsular Malaysia. Trans R Soc Trop Med Hyg 83(1):133-135. https://doi.org/10.1016/0035-9203(89)90739-6

Ottesen EA, Leadbetter JR (2010) Diversity of formyltetrahydrofolate synthetases in the guts of the wood-feeding cockroach Cryptocercus punctulatus and the omnivorous cockroach Periplaneta americana. Appl Environ Microbiol 76(14):4909_ 4913. https://doi.org/10.1128/aem.00299-10

Ozdal M, Ozdal OG, Algur OF (2016) Isolation and characterization of $\alpha$-endosulfan degrading bacteria from the microflora of cockroaches. Pol J Microbiol 65(1):63-68. https://doi.org/10.5604/ 17331331.1197325

Ozdal M, Ozdal OG, Algur OF, Kurbanoglu EB (2017) Biodegradation of $\alpha$-endosulfan via hydrolysis pathway by Stenotrophomonas maltophilia OG2. 3 Biotech 7:113. https://doi.org/10.1007/s13205017-0765-y

Pai HH, Chen WC, Peng CF (2003) Isolation of non-tuberculous mycobacteria from hospital cockroaches (Periplaneta americana). J Hosp Infect 53(3):224-228. https://doi.org/10.1053/jhin.2002. 1355

Pai HH, Chen WC, Peng CF (2004) Cockroaches as potential vectors of nosocomial infections. Infect Control Hosp Epidemiol 25(11):979 984. https://doi.org/10.1086/502330

Pai HH, Chen WC, Peng CF (2005) Isolation of bacteria with antibiotic resistance from household cockroaches (Periplaneta americana and Blattella germanica). Acta Trop 93(3):259-265. https://doi.org/10. 1016/j.actatropica.2004.11.006

Pan Q, Shikano I, Hoover K, Liu T-X, Felton GW (2019) Enterobacter ludwigii, isolated from the gut microbiota of Helicoverpa zea, promotes tomato plant growth and yield without compromising antiherbivore defenses. Arthropod-Plant Inte 13(2):271-278. https:// doi.org/10.1007/s11829-018-9634-9

Parichehreh S, Tahmasbi G, Sarafrazi A, Imani S, Tajabadi N (2018) Isolation and identification of Lactobacillus bacteria found in the gastrointestinal tract of the dwarf honey bee, Apis florea Fabricius, 1973 (Hymenoptera: Apidae). Apidologie 49(3):430-438. https:// doi.org/10.1007/s13592-018-0569-z

Parte AC, Sardà Carbasse J, Meier-Kolthoff JP, Reimer LC, Göker M (2020) List of prokaryotic names with standing in nomenclature (LPSN) moves to the DSMZ. Int J Syst Evol Microbiol. https:// doi.org/10.1099/ijsem.0.004332

Patiño-Navarrete R, Piulachs M-D, Belles X, Moya A, Latorre A, Peretó J (2014) The cockroach Blattella germanica obtains nitrogen from uric acid through a metabolic pathway shared with its bacterial endosymbiont. Biol Lett 10(7):20140407. https://doi.org/10.1098/rsbl. 2014.0407

Perru O (2007) Les insectes et leurs endosymbiotes, leur découverte de Blochmann à Buchner (1880-1930)-Deuxième partie. Publications de la Société Linnéenne de Lyon 76(2):27-37

Petersen LM, Tisa LS (2013) Friend or foe? A review of the mechanisms that drive Serratia towards diverse lifestyles. Can J Microbiol 59(9): 627-640. https://doi.org/10.1139/cjm-2013-0343

Pietri JE, Tiffany C, Liang D (2018) Disruption of the microbiota affects physiological and evolutionary aspects of insecticide resistance in the German cockroach, an important urban pest. PLoS One 13(12): e0207985. https://doi.org/10.1371/journal.pone.0207985

Prado MA, Gir E, Pereira MS, Reis C, Pimenta FC (2006) Profile of antimicrobial resistance of bacteria isolated from cockroaches (Periplaneta americana) in a Brazilian health care institution. Braz J Infect Dis 10(1):26-32. https://doi.org/10.1590/S141386702006000100006

Prajapati VD, Jani GK, Zala BS, Khutliwala TA (2013) An insight into the emerging exopolysaccharide gellan gum as a novel polymer. Carbohydr Polym 93(2):670-678. https://doi.org/10.1016/j. carbpol.2013.01.030

Pramono AK, Sakamoto M, Iino T, Hongoh Y, Ohkuma M (2015) Dysgonomonas termitidis sp. nov., isolated from the gut of the subterranean termite Reticulitermes speratus. Int J Syst Evol Microbiol 65:681-685. https://doi.org/10.1099/ijs.0.070391-0

Quiroz-Castañeda RE, Mendoza-Mejía A, Obregón-Barboza V, Martínez-Ocampo F, Hernández-Mendoza A, Martínez-Garduño F, Guillén-Solís G, Sánchez-Rodríguez F, Peña-Chora G, OrtízHernández L, Gaytán-Colín P, Dantán-González E (2015) Identification of a new Alcaligenes faecalis strain MOR02 and assessment of its toxicity and pathogenicity to insects. Biomed Res Int 2015:570243. https://doi.org/10.1155/2015/570243

Rahmet-Alla M, Rowley AF (1989) Studies on the pathogenicity of different strains of Bacillus cereus for the cockroach, Leucophaea maderae. J Invertebr Pathol 53(2):190-196. https://doi.org/10. 1016/0022-2011(89)90007-4

Rahmet-Alla M, Rowley AF (1990) Studies on the cellular defense reactions of the Madeira cockroach, Leucophaea maderae: in vitro phagocytosis of different strains of Bacillus cereus and their effect on hemocyte viability. J Invertebr Pathol 55(3):350-356. https://doi. org/10.1016/0022-2011(90)90078-K

Rampal L, Oothuman P, Jeffery J, Daud M, Shekhar C, Senan P, Eow L, Suboh Y, Ahmad Z (1983) Bacterial pathogens from the intestinal tracts of various species of cockroaches. Med J Malaysia 38(2):104 107

Ratcliffe NA, Rowley AF (1984) Opsonic activity of insect hemolymph. In: Cheng TC (ed) Invertebrate blood: cells and serum factors. Springer US, Boston, pp 187-204

Richards C, Otani S, Mikaelyan A, Poulsen M (2017) Pycnoscelus surinamensis cockroach gut microbiota respond consistently to a fungal diet without mirroring those of fungus-farming termites. PLoS One 12(10):e0185745. https://doi.org/10.1371/journal.pone. 0185745

Richardson ML, Mitchell RF, Reagel PF, Hanks LM (2010) Causes and consequences of cannibalism in noncarnivorous insects. Annu Rev 
Entomol 55:39-53. https://doi.org/10.1146/annurev-ento-112408085314

Riordan T (2007) Human infection with Fusobacterium necrophorum (necrobacillosis), with a focus on Lemierre's syndrome. Clin Microbiol Rev 20(4):622-659. https://doi.org/10.1128/cmr.0001107

Robertson AR (2007) The isolation and characterization of the microbial flora in the alimentary canal of Gromphadorhina portentosa based on rDNA sequences. East Tennesee State University. Electronic Theses and Dissertations. Paper 2069. https://dc.etsu.edu/etd/2069

Rosas T, García-Ferris C, Domínguez-Santos R, Llop P, Latorre A, Moya A (2018) Rifampicin treatment of Blattella germanica evidences a fecal transmission route of their gut microbiota. FEMS Microbiol Ecol 94(2):fiy002. https://doi.org/10.1093/femsec/fiy002

Rosengaus RB, Mead K, Du Comb WS, Benson RW, Godoy VG (2013) Nest sanitation through defecation: antifungal properties of wood cockroach feces. Naturwissenschaften 100(11):1051-1059. https:// doi.org/10.1007/s00114-013-1110-x

Rossoni RD, dos Santos VM, Figueiredo LMA, Martins CP, Jorge AOC, Junqueira JC (2018) Clinical strains of Lactobacillus reduce the filamentation of Candida albicans and protect Galleria mellonella against experimental candidiasis. Folia Microbiol 63(3):307-314. https://doi.org/10.1007/s12223-017-0569-9

Roth LM (2003) Systematics and phylogeny of cockroaches (Dictyoptera: Blattaria). Orient Insects 37(1):1-186. https://doi. org/10.1080/00305316.2003.10417344

Roth LM, Willis ER (1957) The medical and veterinary importance of cockroaches. Smithsonian Miscellaneous Collections 134(10):1147

Roth L, Willis E (1960) The biotic associations of cockroaches. The Smithsonian Institute, Washington, D.C.

Ryan MP, Adley CC (2010) Sphingomonas paucimobilis: a persistent Gram-negative nosocomial infectious organism. J Hosp Infect 75(3):153-157. https://doi.org/10.1016/j.jhin.2010.03.007

Sabree ZL, Kambhampati S, Moran NA (2009) Nitrogen recycling and nutritional provisioning by Blattabacterium, the cockroach endosymbiont. Proc Natl Acad Sci U S A 106(46):19521-19526. https://doi.org/10.1073/pnas.0907504106

Saitou K, Furuhata K, Fukuyama M (2010) Genotyping of Pseudomonas aeruginosa isolated from cockroaches and human urine. J Infect Chemother 16(5):317-321. https://doi.org/10.1007/s10156-0100055-7

Schauer C, Thompson CL, Brune A (2012) The bacterial community in the gut of the cockroach Shelfordella lateralis reflects the close evolutionary relatedness of cockroaches and termites. Appl Environ Microbiol 78(8):2758-2767. https://doi.org/10.1128/aem. 07788-11

Schauer C, Thompson C, Brune A (2014) Pyrotag sequencing of the gut microbiota of the cockroach Shelfordella lateralis reveals a highly dynamic core but only limited effects of diet on community structure. PLoS One 9(1):e85861. https://doi.org/10.1371/journal.pone. 0085861

Schloss PD (2018) Identifying and overcoming threats to reproducibility, replicability, robustness, and generalizability in microbiome research. mBio 9(3):e00525-e00518. https://doi.org/10.1128/mBio. 00525-18

Shan S, Wang W, Song C, Wang M, Sun B, Li Y, Fu Y, Gu X, Ruan W, Rasmann S (2019) The symbiotic bacteria Alcaligenes faecalis of the entomopathogenic nematodes Oscheius spp. exhibit potential biocontrol of plant- and entomopathogenic fungi. Microb Biotechnol 12(3):459-471. https://doi.org/10.1111/1751-7915. 13365

Sharma S, Prasad RK, Chatterjee S, Sharma A, Vairale MG, Yadav KK (2019) Characterization of Bacillus species with keratinase and cellulase properties isolated from feather dumping soil and cockroach gut. Proc Natl Acad Sci India Sect B Biol Sci 89(3):1079-1086. https://doi.org/10.1007/s40011-018-1026-5

Shi Y-M, Bode HB (2018) Chemical language and warfare of bacterial natural products in bacteria-nematode-insect interactions. Nat Prod Rep 35(4):309-335. https://doi.org/10.1039/C7NP00054E

Siddaramappa S, Narjala A, Viswanathan V, Maliye C, Lakshminarayanan R (2019) Phylogenetic insights into the diversity of Chryseobacterium species. Access Microbiol 1(3):1-15. https:// doi.org/10.1099/acmi.0.000019

Silva MVM, ICR C, de ROMA S, Bornscheuer UT (2019) Biocatalytic cascade reaction for the asymmetric synthesis of L- and Dhomoalanine. ChemCatChem 11(1):407-411. https://doi.org/10. 1002/cctc. 201801413

Sravanthi T, Tushar L, Sasikala C, Ramana CV (2016) Alkalispirochaeta cellulosivorans gen. nov., sp. nov., a cellulose-hydrolysing, alkaliphilic, halotolerant bacterium isolated from the gut of a wood-eating cockroach (Cryptocercus punctulatus), and reclassification of four species of Spirochaeta as new combinations within Alkalispirochaeta gen. nov. Int J Syst Evol Microbiol 66(4):16121619. https://doi.org/10.1099/ijsem.0.000865

Staley JT, Whitman WB (2010) Phylum XIX. Fusobacteria Garrity and Holt 2001, 140. In: Krieg NR, Staley JT, Brown DR, Hedlund BP, Paster BJ, Ward NL, Ludwig W, Whitman WB (eds) Bergey's manual ${ }^{\circledR}$ of systematic bacteriology: volume four the Bacteroidetes, Spirochaetes, Tenericutes (Mollicutes), Acidobacteria, Fibrobacteres, Fusobacteria, Dictyoglomi, Gemmatimonadetes, Lentisphaerae, Verrucomicrobia, Chlamydiae, and Planctomycetes. Springer New York, New York, pp 747-774

Stek M Jr (1982) Cockroaches and enteric pathogens. Trans R Soc Trop Med Hyg 76(4):566-567. https://doi.org/10.1016/0035-9203(82) 90166-3

Strand MA, Brooks MA (1977) Pathogens of Blattidae (cockroaches). Bull World Health Organ 55(1):289-296

Sujada N, Sungthong R, Lumyong S (2014) Termite nests as an abundant source of cultivable Actinobacteria for biotechnological purposes. Microbes Environ 29(2):211-219. https://doi.org/10.1264/jsme2. me13183

Tai V, Carpenter KJ, Weber PK, Nalepa CA, Perlman SJ, Keeling PJ (2016) Genome evolution and nitrogen fixation in bacterial ectosymbionts of a protist inhabiting wood-feeding cockroaches. Appl Environ Microbiol 82(15):4682-4695. https://doi.org/10. 1128/AEM.00611-16

Tang X-L, Liu X, Suo H, Wang Z-C, Zheng R-C, Zheng Y-G (2018) Process development for efficient biosynthesis of 1-DOPA with recombinant Escherichia coli harboring tyrosine phenol lyase from Fusobacterium nucleatum. Bioprocess Biosyst Eng 41(9):13471354. https://doi.org/10.1007/s00449-018-1962-8

Tarshis IB (1962) The cockroach - a new suspect in the spread of infectious hepatitis. Am J Trop Med Hyg 11(5):705-711. https://doi.org/ 10.4269/ajtmh.1962.11.705

Tegtmeier D, Riese C, Geissinger O, Radek R, Brune A (2016a) Breznakia blatticola gen. nov. sp. nov. and Breznakia pachnodae sp. nov., two fermenting bacteria isolated from insect guts, and emended description of the family Erysipelotrichaceae. Syst Appl Microbiol 39(5):319-329. https://doi.org/10.1016/j.syapm.2016.05. 003

Tegtmeier D, Thompson CL, Schauer C, Brune A (2016b) Oxygen affects gut bacterial colonization and metabolic activities in a gnotobiotic cockroach model. Appl Environ Microbiol 82(4):1080-1089. https://doi.org/10.1128/aem.03130-15

Tegtmeier D, Belitz A, Radek R, Heimerl T, Brune A (2018) Ereboglobus luteus gen. nov. sp. nov. from cockroach guts, and new insights into the oxygen relationship of the genera Opitutus and Didymococcus (Verrucomicrobia: Opitutaceae). Syst Appl Microbiol 41(2):101-112. https://doi.org/10.1016/j.syapm.2017. 10.005 
Thapa S, Mishra J, Arora N, Mishra P, Li H, O’Hair J, Bhatti S, Zhou S (2020) Microbial cellulolytic enzymes: diversity and biotechnology with reference to lignocellulosic biomass degradation. Rev Environ Sci Bio 19:621-648. https://doi.org/10.1007/s11157-020-09536-y

Thomas F, Hehemann J-H, Rebuffet E, Czjzek M, Michel G (2011) Environmental and gut Bacteroidetes: the food connection. Front Microbiol 2:93. https://doi.org/10.3389/fmicb.2011.00093

Tilahun B, Worku B, Tachbele E, Terefe S, Kloos H, Legesse W (2012) High load of multi-drug resistant nosocomial neonatal pathogens carried by cockroaches in a neonatal intensive care unit at Tikur Anbessa specialized hospital, Addis Ababa, Ethiopia. Antimicrob Resist Infect Control 1(1):12. https://doi.org/10.1186/2047-2994-112

Tinker KA, Ottesen EA (2016) The core gut microbiome of the American cockroach, Periplaneta americana, is stable and resilient to dietary shifts. Appl Environ Microbiol 82(22):6603-6610. https://doi.org/ 10.1128/aem.01837-16

Tinker KA, Ottesen EA (2020) Phylosymbiosis across deeply diverging lineages of omnivorous cockroaches (order Blattodea). Appl Environ Microbiol 86(7):e02513-e02519. https://doi.org/10.1128/ aem.02513-19

Tokuda G, Elbourne LDH, Kinjo Y, Saitoh S, Sabree Z, Hojo M, Yamada A, Hayashi Y, Shigenobu S, Bandi C, Paulsen IT, Watanabe H, Lo N (2013) Maintenance of essential amino acid synthesis pathways in the Blattabacterium cuenoti symbiont of a wood-feeding cockroach. Biol Lett 9(3):20121153. https://doi.org/ 10.1098/rsbl.2012.1153

Trinkerl M, Breunig A, Schauder R, König H (1990) Desulfovibrio termitidis sp. nov., a carbohydrate-degrading sulfate-reducing bacterium from the hindgut of a termite. System Appl Microbiol 13(4): 372-377. https://doi.org/10.1016/S0723-2020(11)80235-3

Um S, Fraimout A, Sapountzis P, Oh D-C, Poulsen M (2013) The fungusgrowing termite Macrotermes natalensis harbors bacillaeneproducing Bacillus sp. that inhibit potentially antagonistic fungi. Sci Rep 3:3250. https://doi.org/10.1038/srep03250

van Dijl J, Hecker M (2013) Bacillus subtilis: from soil bacterium to super-secreting cell factory. Microb Cell Factories 12:3. https://doi. org/10.1186/1475-2859-12-3

Vera-Ponce de León A, Jahnes BC, Duan J, Camuy-Vélez LA, Sabree ZL (2020) Cultivable, host-specific Bacteroidetes symbionts exhibit diverse polysaccharolytic strategies. Appl Environ Microbiol 86(8): e00091-e00020. https://doi.org/10.1128/aem.00091-20

Vicente CSL, Mondal SI, Akter A, Ozawa S, Kikuchi T, Hasegawa K (2018) Genome analysis of new Blattabacterium spp., obligatory endosymbionts of Periplaneta fuliginosa and $P$. japonica. PLoS One 13(7):e0200512. https://doi.org/10.1371/journal.pone.0200512

Vinokurov K, Taranushenko Y, Krishnan N, Sehnal F (2007) Proteinase, amylase, and proteinase-inhibitor activities in the gut of six cockroach species. J Insect Physiol 53(8):794-802. https://doi.org/10. 1016/j.jinsphys.2007.02.019

Vivero RJ, Mesa GB, Robledo SM, Herrera CXM, Cadavid-Restrepo G (2019) Enzymatic, antimicrobial, and leishmanicidal bioactivity of gram-negative bacteria strains from the midgut of Lutzomyia evansi, an insect vector of leishmaniasis in Colombia. Biotechnol Rep 24: e00379. https://doi.org/10.1016/j.btre.2019.e00379

Vršanský P (2004) Cretaceous Gondwanian cockroaches (Insecta: Blattaria). Entomological Problems 34(1-2):49-54

Walter J (2008) Ecological role of lactobacilli in the gastrointestinal tract: implications for fundamental and biomedical research. Appl Environ Microbiol 74(16):4985-4996. https://doi.org/10.1128/ aem.00753-08

Wang Z, Shi Y, Qiu Z, Che Y, Lo N (2017) Reconstructing the phylogeny of Blattodea: robust support for interfamilial relationships and major clades. Sci Rep 7(1):3903. https://doi.org/10.1038/s41598017-04243-1
Wang P, Yu Z, Zhao J, Zhang H (2018) Do microbial communities in an anaerobic bioreactor change with continuous feeding sludge into a full-scale anaerobic digestion system? Bioresour Technol 249:8998. https://doi.org/10.1016/j.biortech.2017.09.191

Wang R, Wei S, Jia P, Liu T, Hou D, Xie R, Lin Z, Ge J, Qiao Y, Chang X, Lu L, Tian S (2019) Biochar significantly alters rhizobacterial communities and reduces $\mathrm{Cd}$ concentration in rice grains grown on Cd-contaminated soils. Sci Total Environ 676:627-638. https://doi. org/10.1016/j.scitotenv.2019.04.133

Wannigama DL, Dwivedi R, Zahraei-Ramazani A (2014) Prevalence and antibiotic resistance of Gram-negative pathogenic bacteria species isolated from Periplaneta americana and Blattella germanica in Varanasi, India. J Arthropod-borne Dis 8(1):10-20

Ware JL, Litman J, KLASS KD, Spearman LA (2008) Relationships among the major lineages of Dictyoptera: the effect of outgroup selection on dictyopteran tree topology. Syst Entomol 33(3):429450

Wasi S, Tabrez S, Ahmad M (2013) Use of Pseudomonas spp. for the bioremediation of environmental pollutants: a review. Environ Monit Assess 185(10):8147-8155. https://doi.org/10.1007/s10661013-3163-x

Waters JL, Ley RE (2019) The human gut bacteria Christensenellaceae are widespread, heritable, and associated with health. BMC Biol 17(1):83. https://doi.org/10.1186/s12915-019-0699-4

Wharton ML, Wharton DRA (1957) The production of sex attractant substance and of oöthecae by the normal and irradiated American cockroach, Periplaneta americana L. J Insect Physiol 1(3):229 239. https://doi.org/10.1016/0022-1910(57)90038-0

Willis ER, Lewis N (1957) The longevity of starved cockroaches. J Econ Entomol 50(4):438-440. https://doi.org/10.1093/jee/50.4.438

Yang Y-j, Zhang N, S-q J, Lan X, K-d Z, Shen Y-1, F-1 L, J-f N (2014) Dysgonomonas macrotermitis sp. nov., isolated from the hindgut of a fungus-growing termite. Int J Syst Evol Microbiol 64:2956-2961. https://doi.org/10.1099/ijs.0.061739-0

Younes M, Aggett P, Aguilar F, Crebelli R, Dusemund B, Filipič M, Frutos MJ, Galtier P, Gundert-Remy U, Kuhnle GG, Lambré C, Leblanc J-C, Lillegaard IT, Moldeus P, Mortensen A, Oskarsson A, Stankovic I, Waalkens-Berendsen I, Woutersen RA, Wright M, Herman L, Tobback P, Pizzo F, Smeraldi C, Tard A, Papaioannou A, Gott D (2017) Safety of nisin (E 234) as a food additive in the light of new toxicological data and the proposed extension of use. EFSA J 15(12):e05063. https://doi.org/10.2903/j.efsa.2017.5063

Yumoto I, Hirota K, Yoshimune K (2011) Environmental distribution and taxonomic diversity of alkaliphiles. In: Horikoshi K (ed) Extremophiles handbook. Springer Japan, Tokyo, pp 55-79

Yun J, Hwang J-S, Lee DG (2017) The antifungal activity of the peptide, periplanetasin-2, derived from American cockroach Periplaneta americana. Biochem J 474(17):3027-3043. https://doi.org/10. 1042/bcj20170461

Zarei O, Shokoohizadeh L, Hossainpour H, Alikhani MY (2018) Molecular analysis of Pseudomonas aeruginosa isolated from clinical, environmental and cockroach sources by ERIC-PCR. BMC Res Notes 11(1):668. https://doi.org/10.1186/s13104-018-3765-z

Zhang F, Yang R (2019) Life history and functional capacity of the microbiome are altered in beta-cypermethrin-resistant cockroaches. Int J Parasitol 49(9):715-723. https://doi.org/10.1016/j.ijpara.2019. 04.006

Zhang P-B, Yan X, Qiu X-H, Han R-C (2010) Application of transgenic Enterobacter cloacae with the insecticidal tcdA 1 B 1 genes for control of Coptotermes formosanus (isoptera: Rhinotermitidae) in the field. Sociobiology 56(1):27-38

Zhang F, Huang YH, Liu SZ, Zhang L, Li BT, Zhao XX, Fu Y, Liu JJ, Zhang XX (2013a) Pseudomonas reactans, a bacterial strain isolated from the intestinal flora of Blattella germanica with antiBeauveria bassiana activity. Environ Entomol 42(3):453-459. https://doi.org/10.1603/en12347 
Zhang Z, Schneider JW, Hong Y (2013b) The most ancient roach (Blattodea): a new genus and species from the earliest late carboniferous (Namurian) of China, with a discussion of the phylomorphogeny of early blattids. J Syst Palaeontol 11(1):27-40. https://doi.org/10.1080/14772019.2011.634443

Zhang F, Yang C, Zhang X, Zhu H, Zhao D, Huang Y (2020) Isolation of an anti-entomopathogenic fungal protein secreted from
Pseudomonas aeruginosa BGf-2: An intestinal bacteriam of Blattella germanica (L.). J Invertebr Pathol 173:107371. https:// doi.org/10.1016/j.jip.2020.107371

Publisher's note Springer Nature remains neutral with regard to jurisdictional claims in published maps and institutional affiliations. 